\title{
ADSC-Based Cell Therapies for Musculoskeletal Disorders: A Review of Recent Clinical Trials
}

\author{
Seahyoung Lee ${ }^{1}$, Dong-Sik Chae ${ }^{2}$, Byeong-Wook Song ${ }^{1}{ }^{\mathbb{D}}$, Soyeon $\operatorname{Lim}^{1}{ }^{\mathbb{D}}$, Sang Woo Kim ${ }^{1}$, Il-Kwon $\operatorname{Kim}^{1}$,* \\ and Ki-Chul Hwang ${ }^{1, *}$
}

1 Institute for Bio-Medical Convergence, College of Medicine, Catholic Kwandong University, Gangneung 210-701, Korea; sam1017@ish.ac.kr (S.L.); songbw@cku.ac.kr (B.-W.S.); slim724@cku.ac.kr (S.L.); swk74@cku.ac.kr (S.W.K.)

2 Department of Orthopedic Surgery, International St. Mary's Hospital, Catholic Kwandong University, Gangneung 210-701, Korea; drchaeos@gmail.com

* $\quad$ Correspondence: ilkwonkim@ish.ac.kr (I.-K.K.); kchwang@cku.ac.kr (K.-C.H.); Fax: +82-32-290-2774 (K.-C.H.)

Citation: Lee, S.; Chae, D.-S.; Song, B.-W.; Lim, S.; Kim, S.W.; Kim, I.-K.; Hwang, K.-C. ADSC-Based Cell Therapies for Musculoskeletal Disorders: A Review of Recent Clinical Trials. Int. J. Mol. Sci. 2021, 22, 10586. https://doi.org/ 10.3390/ijms221910586

Academic Editor: Luisa Barzon

Received: 10 August 2021

Accepted: 25 September 2021

Published: 30 September 2021

Publisher's Note: MDPI stays neutral with regard to jurisdictional claims in published maps and institutional affiliations.

Copyright: (c) 2021 by the authors. Licensee MDPI, Basel, Switzerland. This article is an open access article distributed under the terms and conditions of the Creative Commons Attribution (CC BY) license (https:/ / creativecommons.org/licenses/by/ $4.0 /)$.
Abstract: Recently published clinical trials involving the use of adipose-derived stem cells (ADSCs) indicated that approximately one-third of the studies were conducted on musculoskeletal disorders (MSD). MSD refers to a wide range of degenerative conditions of joints, bones, and muscles, and these conditions are the most common causes of chronic disability worldwide, being a major burden to the society. Conventional treatment modalities for MSD are not sufficient to correct the underlying structural abnormalities. Hence, ADSC-based cell therapies are being tested as a form of alternative, yet more effective, therapies in the management of MSDs. Therefore, in this review, MSDs subjected to the ADSC-based therapy were further categorized as arthritis, craniomaxillofacial defects, tendon/ligament related disorders, and spine disorders, and their brief characterization as well as the corresponding conventional therapeutic approaches with possible mechanisms with which ADSCs produce regenerative effects in disease-specific microenvironments were discussed to provide an overview of under which circumstances and on what bases the ADSC-based cell therapy was implemented. Providing an overview of the current status of ADSC-based cell therapy on MSDs can help to develop better and optimized strategies of ADSC-based therapeutics for MSDs as well as help to find novel clinical applications of ADSCs in the near future.

Keywords: adipose-derived stem cell; clinical trials; musculoskeletal disorders

\section{Introduction}

Stem cells refer to a group of unspecialized cells with the ability to differentiate into many lineage-specific cell types and to renew themselves. Although embryonic stem cells are known to have the most powerful pluripotency [1], their ethical issues and limited availability have promoted the search for adult stem cells for tissue regeneration and stemcell-based therapeutics [2]. One of the well-known examples of such adult stem cells are bone-marrow-derived mesenchymal stem cells (BM-MSCs), and since their first discovery in 1970 [3], they have been considered the major players in stem-cell-based therapies, being the most frequently used cells in clinical settings [4]. However, the invasive harvesting procedure of BM-MSC poses unnecessary pain and/or risk of infection, and it may also yield an insufficient amount of cells for clinical applications [5]. Such drawbacks of BMMSCs have driven yet another search, and a number of adult stem cells from different sources, such as adipose tissue, umbilical cord, dental pulp, and endometrium, have been reported [6]. Among these cells, adipose-derived stem cells (ADSCs) are considered good candidates for autologous cell therapy since they can be obtained in high numbers from the abundant adipose tissue of the body [7].

Since the very first isolation and identification of human ADSCs in 2002 [8], numerous strategies to utilize ADSCs as a main component of regenerative cell therapeutics have 
been developed and tested. As the name indicates, ADSCs refer to adult mesenchymal stem cells obtained from adipose tissue. In terms of their characteristics, very similar to the BM-MSCs, they possess a self-renewal ability and multi-potency. On the other hand, unlike the BM-MSCs, a sufficient amount of ADSCs can be easily obtained from adipose tissue with a minimally invasive procedure such as liposuction, and adherent ADSCs can be expanded in vitro, maintaining the capacity to differentiate [9]. Such ease of harvesting and multi-potency of ADSCs make them attractive adult stem cells for repairing damaged tissues and organs, and the PubMed search for recently published clinical trials (within the last 10 years) involving the use of ADSCs indicated that approximately one-third of the published clinical studies were conducted on musculoskeletal disorders (MSD).

MSD refers to a wide range of degenerative conditions of joints, bones, and muscles. The most common examples of MSD include osteoarthritis, osteoporosis, rheumatoid arthritis, and sports injuries, and these conditions are also the most common causes of chronic disability worldwide, being a major burden to society [10]. Conventional treatment modalities for MSD such as pharmacological and non-pharmacological therapies are used mainly to reduce the pain associated with these conditions. In other words, these treatment options may relieve the symptoms and the pain associated with musculoskeletal disorders, but they are often associated with a wide range of undesirable side effects and are not sufficient to correct the underlying structural abnormalities. Hence, it is not so surprising that ADSC-based cell therapies are continuously being tested as an alternative, yet more effective, therapy in the management of musculoskeletal conditions.

Therefore, in this concise review, focusing on the type of MSDs subjected to therapeutic application of ADSCs in the recently published clinical studies, a brief characterization of MSDs as well as corresponding conventional therapeutic approaches including regenerative therapies using stem cell other than ADSCs will be discussed to provide an idea of under which circumstances and on what bases the ADSC-based cell therapy was implemented. By providing an overview of the current status of ADSC-based cell therapy on MSDs, we hope that this concise review can help to develop better and optimized strategies of ADSC-based therapeutics for MSDs as well as to find novel clinical applications of ADSCs in the near future.

\section{MSD as a Major Target of ADSC-Based Cell Therapeutics}

The PubMed search conducted on 1 June 2021 using "adipose derived stem cells or adipose derived regenerative cells or adipose derived stromal cells" as keywords with a filtering condition of article type "clinical trial" and a publication date of "10 years" came up with 167 studies. Among those articles, the number of original clinical studies that involved human subjects was 106, but 28 of them used stromal vascular fractions (SVFs) that are known to contain ADSCs [11] instead of isolated ADSCs. Since SVFs may be missing or without additional biological impact as compared to the standard cell therapy using isolated ADSCs only, those 28 studies are not covered by this review.

Out of a total of 78 studies, about one-third of the studies (21 studies) involved the application of ADSCs on MSCs, including but not limited to osteoarthritis, achilles tendinopathy, and rotator cuff tears. The top three disease categories also included gastrointestinal (14 studies) and circulatory (10 studies) categories (Figure 1). The details of each individual study covered by this review are described in the following subsections cartegorized by the type of musculoskeletal disorders (MSD) targeted. 
Out of a total of 78 clinical studies involving therapeutic use of isolated ADSCs..

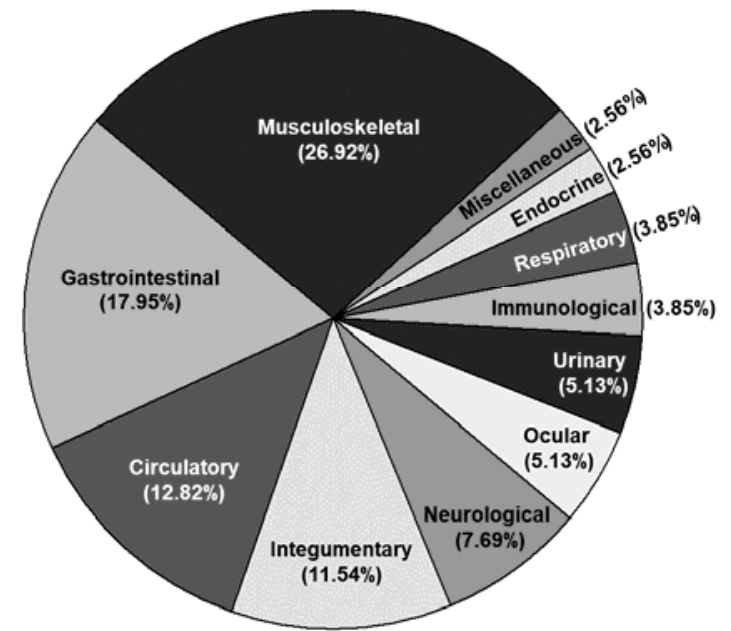

Figure 1. Different disorders subjected to isolated ADSC-based therapeutics are categorized by the systems the targeted tissue/organ belong to, and the ratio of each category is indicated.

\section{Type of MSDs Targeted}

\subsection{Arthritis}

Further analysis of the 21 clinical studies involving the use of isolated ADSCs on MSDs indicated that arthritis (10 osteoarthritis and 1 rheumatoid arthritis) was the most frequently targeted disorder of the musculoskeletal system. The clinical studies of ADSC-based cell therapy on arthritis are listed in Table 1. 
Table 1. Summary of clinical studies examined therapeutic use of hADSCs on arthritis for the last 10 years.

\begin{tabular}{|c|c|c|c|c|c|c|c|}
\hline & Target Disorder & $\begin{array}{l}\text { No. of Patients Treated } \\
\text { (Age: Mean } \pm \text { SD) }\end{array}$ & ADSC Type & $\begin{array}{c}\text { ADSC } \\
\text { Delivery }\end{array}$ & $\begin{array}{l}\text { Study } \\
\text { Outcome }\end{array}$ & Year & Ref. No. \\
\hline 1 & Knee osteoarthritis & $25(54.20 \pm 9.30)$ & $\begin{array}{l}\text { Autologous, derived from } \\
\text { infrapatellar fat pad }\end{array}$ & $\begin{array}{l}\text { Infrapatellar injection } \\
\text { with PRP }\end{array}$ & $\begin{array}{l}\text { No major AEs }{ }^{2} \text { with significantly } \\
\text { increase Lysholm, Tegner activity } \\
\text { scale, and VAS }{ }^{3} \text { score }\end{array}$ & 2012 & [12] \\
\hline 2 & Knee osteoarthritis & $18(63.0 \pm 12.49)$ & $\begin{array}{l}\text { Autologous, derived from } \\
\text { abdominal fat }\end{array}$ & Intra-articular injection & $\begin{array}{l}\text { Improved function and pain } \\
\text { without adverse events, reduced } \\
\text { cartilage defects }\end{array}$ & 2014 & [13] \\
\hline 3 & Knee cartilage defects & $40(38.75 \pm 9.56)$ & $\begin{array}{l}\text { Autologous, derived from } \\
\text { buttocks }\end{array}$ & $\begin{array}{l}\text { After microfracture, } \\
\text { intra-articular injection with } \\
\text { fibrin glue }\end{array}$ & $\begin{array}{l}\text { Improved KOOS }{ }^{4} \text { pain and } \\
\text { symptom sub score }\end{array}$ & 2016 & [14] \\
\hline 4 & Knee osteoarthritis & $18(64.63 \pm 9.37)$ & $\begin{array}{l}\text { Autologous, derived from } \\
\text { abdominal fat }\end{array}$ & Intra-articular injection & Safe, without SAEs ${ }^{5}$ & 2016 & [15] \\
\hline 5 & $\begin{array}{c}\text { Refractory rheumatoid } \\
\text { arthritis }\end{array}$ & $46(53.96 \pm 20.64)$ & Allogeneic (Cx611) & Intravenous injection & $\begin{array}{l}\text { Well tolerated with no evidence of } \\
\text { dose-related toxicity, but some } \\
\text { AEs and SAEs }\end{array}$ & 2017 & [16] \\
\hline 6 & Osteoarthritis & $18(54.8 \pm 17.73)$ & $\begin{array}{c}\text { Autologous, isolated from } \\
\text { lipoaspirates }\end{array}$ & $\begin{array}{l}\text { Intra-articular injection, } \\
\text { repeated }\end{array}$ & $\begin{array}{l}\text { Safe and improved pain, function, } \\
\text { and cartilage volume }\end{array}$ & 2018 & [17] \\
\hline 7 & Knee osteoarthritis & $20(54.65 \pm 11.99)$ & $\begin{array}{l}\text { Autologous, derived from } \\
\text { abdominal fat }\end{array}$ & Intra-articular injection & $\begin{array}{l}\text { No SAEs, clinically significant } \\
\text { pain, and functional improvement }\end{array}$ & 2019 & [18] \\
\hline 8 & Knee osteoarthritis & $12(62.25 \pm 6.50)$ & $\begin{array}{l}\text { Autologous, derived from } \\
\text { abdominal fat }\end{array}$ & Intra-articular injection & $\begin{array}{l}\text { Significant improvement of the } \\
\text { WOMAC }^{6} \text { score without SAEs }\end{array}$ & 2019 & [19] \\
\hline 9 & Knee osteoarthritis & $26(55.03 \pm 9.19)$ & $\begin{array}{l}\text { Autologous, derived from } \\
\text { abdominal fat }\end{array}$ & Intra-articular injection & $\begin{array}{l}\text { Significant improvements in joint } \\
\text { function, pain, quality of life, and } \\
\text { cartilage regeneration }\end{array}$ & 2019 & {$[20]$} \\
\hline 10 & Subtalar joint arthritis & $52(56.9: 20.3-79.6)^{6}$ & Allogeneic & $\begin{array}{l}\text { ADSC loaded, partially } \\
\text { demineralized cancellous bone } \\
\text { (AlloSource) was grafted }\end{array}$ & $\begin{array}{l}\text { Good clinical outcomes in spite of } \\
\text { the high non-union rates }\end{array}$ & 2019 & {$[21]$} \\
\hline 11 & Knee osteoarthritis & $18(54.77 \pm 17.79)$ & Allogeneic & Intra-articular injection & $\begin{array}{l}\text { a possible compositional changes } \\
\text { of cartilage, significant reduction } \\
\text { in WOMAC }{ }^{7} \text { and SF- } 36^{8} \text { scores }\end{array}$ & 2019 & [22] \\
\hline
\end{tabular}

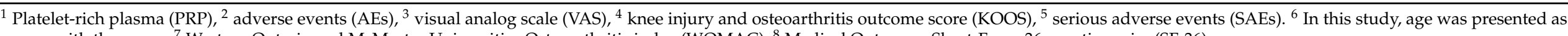
means with the range. ${ }^{7}$ Western Ontario and McMaster Universities Osteoarthritis index (WOMAC), ${ }^{8}$ Medical Outcomes Short-Form-36 questionnaire (SF-36). 
Classification by the anatomic sites affected (so targeted by the ADSC-based cell therapy) indicated that osteoarthritis (OA) of the knee was the major MSD with nine studies, and there were two studies for osteoarthritis of the ankle and refractory rheumatoid arthritis. As the most common musculoskeletal progressive condition, $\mathrm{OA}$ is a degenerative disease of the joints that displays clinical signs such as cartilage loss, osteophyte formation, and periarticular bone deformation [23]. Various pro-inflammatory cytokines and growth factors such as interleukin-1, tumor necrosis factor-alpha, transforming growth factor-beta, and matrix metalloproteinase are known to contribute to the progression of OA [24]. As conservative treatments, pharmacological agents such as acetaminophen, aspirin, and oral non-steroidal anti-inflammatory drugs (NSAIDs) are recommended for early management of $\mathrm{OA}$ [25] and surgical interventions such as total joint replacements may be necessary for severe OA with persisting pains [26]. However, pharmacological agents are not sufficient to correct the underlying structural abnormalities so that they are not able to prevent the progressive degeneration of the OA joint [27]. In the case of total joint replacement, although it is generally successful with enhanced mobility and reduced pain, it also has its own disadvantages such as a substantial risk of thrombosis and infection as a major surgical procedure and a high cost to cover hospital care and rehabilitation, which is similar to many other major surgeries [28]. Such limitations of conservative treatments promoted the development of less-invasive approaches for the management of OA.

Intra-articular injection of hyaluronic acid or platelet-rich plasma (PRP) $[29,30]$, as well as MSCs, are the well-known examples of such less-invasive approaches. From the early 2000s, MSC-based cell therapy for OA has been suggested [31], and the emergence of MSCbased cell therapy in OA treatment is based on the ease of harvesting, the safety, and the cartilage differentiation potential of MSCs [13,32] and their paracrine and immunomodualtory effects [33-35]. The first clinical study that examined the effect of BM-MSC on articular cartilage defect was almost two decades old [36]. In that particular study, where the effect of BM-MSC transplantation was compared to that of a high tibial osteotomy in treating the articular cartilage defect, 42 weeks of transplantation resulted in hyaline cartilage-like tissue regeneration and improvement of both the arthroscopic and histological grading score, suggesting the clinical feasibility of MSC-based cell therapy for OA. Thereafter, such a beneficial effect of MSC-based cell therapy on OA has been further validated in many different pre-clinical and clinical studies [33], and it was adopted as a possible alternative to conventional therapeutics for treating other diseases as well [37].

Similarly, the effect of ADSCs on OA treatment has been investigated in animals of various species first, and after preclinical animal studies showed evidence of ADSCmediated cartilage regeneration [38-40], the feasibility of using ADSCs for OA treatment in humans has been further scrutinized. One of the early studies tested the clinical potential of ADSCs in treating OA-utilized autologous ADSCS in the form of SVF with plateletrich plasma and hyaluronic acid [41]. In this particular study, two human subjects with knee OA were treated, and regeneration of cartilage-like tissue was confirmed by magnetic resonance imaging (MRI). Thereafter, more studies using ADSCs for treating OA in humans, as indicated in Table 1, became available, accumulating evidence of cartilage regeneration.

The majority (eight out of nine) of the studies on OA utilized autologous ADSCs [12-15,17-20], and ADSCs were most frequently derived from abdominal fat (five out of nine) $[13,15,18-20]$. The number of ADSCs for a single injection ranged from $1.89 \times 10^{6}$ to $1.0 \times 10^{8}$, and the most frequently used dose was $5 \times 10^{7}[15,17,20,22]$. The method used to deliver ADSCs was intra-articular injection of ADSC solution, except the three studies either used platelet-rich plasma (PRP) [12] or fibrin glue [14] or partially demineralized cancellous bone [21] in combination with ADSC solution. No study on OA reported any treatment-related significant adverse events suggesting the safety of using ADSCs in treating OA. However, the study examined the effect of intravenously injected allogeneic ADSCs on refractory-rheumatoid-arthritis-reported adverse events (AEs)—although most of the AEs were of mild-to-moderate intensity [16]. In that particular study, transient fever was the most frequent treatment-related AE. Although it was not 
clearly determined, some form of infusion reaction was suggested as the underlying mechanism [42]. Additionally, there was one case of a lacunar infarction (left hemihypoesthesia and paretic ataxic gait), which was regarded as the dose-limiting toxicity. Since no apparent cause was determined, it was considered as likely treatment-related. Nevertheless, the treatment was well tolerated without dose-related toxicity, and it even demonstrated signs for potential therapeutic effects, calling for further research to investigate.

In terms of the clinical efficacy of ADSCs on OA, except studies with other primary purposes such as evaluating the safety of using ADSCs $[15,16]$ or validating multicompositional MRI as an effective tool for evaluating cartilage repair [22], most of the studies reported significantly improved pain and/or function. In the study where the patients received infrapatellar fat pad-derived MSCs with PRP, both the mean Lysholm score [43] and the Tegner activity scale [44], which measure activities of daily living, significantly increased in the experimental group compared to the control group that matched in terms of patient age and sex and follow-up period, suggesting improved knee function [12]. Furthermore, ADSC treatment significantly decreased the VAS score, indicating an improvement in the patient's pain.

In another study, the safety and efficacy of autologous ADSCs without adjuvants indicated that treatment with $1.0 \times 10^{8}$ ADSCs resulted in a 39\% reduction of the WOMAC score, which measures pain, stiffness, and physical functioning of the joints [45] and a $45 \%$ decrease in the VAS at six months following injection. Furthermore, in radiological evaluation, it was found that the size of cartilage defects significantly decreased both in the medial femoral ( $40 \%$ decrease) and the tibial condyles ( $49 \%$ decrease) as well as in the lateral femoral ( $51 \%$ decrease) and the tibial condyles ( $46 \%$ decrease) at six months. Additionally, the cartilage volume significantly increased over the six months both in the medial femoral (14\% increase) and the tibial condyles (22\% increase) [13], suggesting regeneration of damaged cartilage.

While these studies involved a single injection of ADSCs, there are also studies that utilized multiple injections of ADSCs [17,18]. For example, a study published in 2018 examined the long-term (96 weeks) safety and efficacy of repeated injection of ADSCs (with an interval of 48 weeks between the first two and the third injection), and the results indicated that the WOMAC score gradually reduced over time with a mean improvement rate of $27.81,48.63,39.07,47.95$, and $53.29 \%$, at the 12th, 24th, 48th, 72nd, and 96th weeks following the initial injection, respectively. Furthermore, MRI evaluation showed that an increase in the cartilage thickness was more significant after the third injection compared with the first two injections, suggesting enhanced benefits of repeated injections [17]. Additional clinical-efficacy-related findings from other studies are also summarized in Table 1.

Altogether, these studies demonstrated that using ADSC-based cell therapy on OA is safe, and it produced promising results so that further clinical studies to verify its safety and efficacy as well as to set up a standardized therapeutic protocol are recommended. According to the ClinicalTrials.gov (accessed on 24 September 2021), 12 clinical trials to examine the effect of ADSCs on OA are ongoing (categories counted; recruiting, not yet recruiting, active, not recruiting, and enrolling by invitation) as of now.

In $\mathrm{OA}$ or degenerative join disease, damages to chondroblasts, chondrocytes, and the extracellular matrix (ECM) induced by various factors, such as oxidative stress, inflammatory factors, and mitochondrial dysfunction [46], initiate the degradation of cartilage tissue, which eventually leads to structural failure and loss of function [47]. Therefore, the fundamental premise of MSC-based therapeutic approaches for treating OA is that MSCs both/either directly adhere and become incorporated into the host tissue for osteogenic differentiation and/or exert reparatory effects on host cells via a paracrine mechanism, and empirical evidence indicated that those two mechanisms may synergistically work together [48]. 
For direct incorporation of MSCs in treating OA, two different studies have reported direct adherence and incorporation of injected MSCs, although they were not ADSCs. First, MSCs isolated from synovium of rats were used for meniscus cartilage regeneration, and the results indicated that the intra-articular injected MSCs migrated and adhered to the site of injury, and filled the meniscal defect [49]. In another study, umbilical-cord-blood-derived (UCB) MSCs with hyaluronic acid (HA) were utilized to treat rabbit joint articular cartilage defects, and the delivered UCB-MSCs adhered to the site of injury and regenerated cartilage comparable to normal cartilage tissue in terms of cellular structure and collagen organization [50]. Nevertheless, although those previous studies have clearly demonstrated that the delivered MSCs definitely attached at the site of injury, whether those incorporated MSCs were indeed differentiated into chondroblasts and/or chondrocytes is still inconclusive. In fact, other studies involved implanted a cell-tracking strategy that suggested that the adherence of MSCs at the site of cartilage defects was necessary, but those adhered MSCs were not necessarily differentiated into new chondroblasts and/or chondrocytes [48,51].

As for the paracrine effects, MSCs are known to secrete a wide range of bioactive factors, such as proteins, nucleic acids, proteasomes, exosomes, microRNA, and membrane vesicles, in response to the surrounding environment, and those bioactive factors affect various biological entities including the immune system, apoptosis, and growth and differentiation [52]. The secretome of MSCs can be categorized into the following three classes: growth factors, cytokines, and extracellular vesicles [53,54]. The growth factors and cytokines released from MSCs can be either pro-inflammatory or anti-inflammatory [54]. Vascular endothelial growth factor (VEGF), tumor necrosis factor $\beta 1$ (TGF- $\beta 1$ ), interleukin 13 (IL-13), and insulin-like growth factor (IGF-1) are some examples of anti-inflammatory mediators released from MSCs [55-59]. Although the secretome of MSC also includes pro-inflammatory mediators such as IL-1b, IL-6, IL-8, IL-9, and matrix metalloproteinase 3 (MMP-3) [60-63] and the final effect of MSCs on inflammation is decided by the temporal and spatial net effect of those growth factors and cytokines, mounting evidence indicates that MSCs more than often produces an overall anti-inflammatory effect [64-66].

It should be noted that although those growth factors and cytokines were categorized as pro- and anti-inflammatory mediators for the sake of discussion, the true nature of any given one of them is too complicated to be described by a single biological function. For example, IGF-I and TGF- $\beta$ have been demonstrated to enhance the chondrogenic differentiation of MSCs [67], and they are also reported to increase the production of cartilage matrix components such as proteoglycan, type II collagen, and aggrecan in chondrocytes [68]. Furthermore, IGF-1 is known to regulate cellular apoptosis [69], and, in fact, it has been demonstrated that it can suppress apoptosis via the Src/PI-3K/AKT pathway in chondrocytes [70]. Therefore, it is most likely that those bioactive molecules from MSCs work together in a complex signaling network to produce an overall reparative impact on damaged cartilage.

Speaking of the anti-apoptotic effect of MSC-derived bioactive molecules, it has been reported that co-culturing with MSCs decreased the expression of pro-apoptotic proteins such as caspase 3 and Bax, while it increased the expression of anti-apoptotic protein, Bcl-2, in alveolar macrophages [71], suggesting the anti-apoptotic effect of MSC-derived secretome. Additionally, evidence more directly related to the anti-apoptotic effect of ADSC-derived secretome on chondrocytes has been reported as well [72]. Based on those findings, it can be speculated that the growth factors and the cytokines released by ADSCs may prevent the death of chondrocytes, in addition to suppressing the inflammatory response in the diseased joint. Therefore, as the underlying mechanisms of ADSC-induced cartilage regeneration, it seems that the incorporation of stem both cells and paracrine effects contributes to the regenerative effect of MSCs, and it is likely that the same can be applied to ADSCs as well. 


\subsection{Craniomaxillofacial Defects}

Out of 20 clinical studies involving the use of isolated ADSCs on musculoskeletal disorders, 3 studies were on craniofacial defects, namely, calvarial defects, caraniofacial microsomia, and cranio-maxillofacial hard-tissue defects (Table 2).

Table 2. Summary of clinical studies involving the use of isolated hADSCs on craniomaxillofacial defects for the last 10 years.

\begin{tabular}{|c|c|c|c|c|c|c|c|}
\hline & Target Disorder & $\begin{array}{c}\begin{array}{c}\text { No. of Patients } \\
\text { Treated } \\
\text { (Age: Mean } \pm \text { SD) }\end{array} \\
\end{array}$ & ADSC Type & $\begin{array}{c}\text { ADSC } \\
\text { Delivery }\end{array}$ & $\begin{array}{c}\text { Study } \\
\text { Outcome }\end{array}$ & Year & Ref. No. \\
\hline 1 & Calvarial defects & $4(63.8: 59-75)^{1}$ & $\begin{array}{l}\text { Autologous, } \\
\text { derived from } \\
\text { abdominal fat }\end{array}$ & $\begin{array}{l}\text { ADSCs containing } \\
\text { betaTCP }{ }^{2} \\
\text { granules were laid } \\
\text { on the dura }\end{array}$ & $\begin{array}{c}\text { No } \\
\text { complications } \\
\text { with satisfactory } \\
\text { ossification }\end{array}$ & 2011 & [73] \\
\hline 2 & $\begin{array}{l}\text { Craniofacial } \\
\text { microsomia }\end{array}$ & $7(12.10 \pm 2.20)$ & $\begin{array}{l}\text { Autologous, } \\
\text { derived from } \\
\text { abdominal fat }\end{array}$ & $\begin{array}{c}\text { Subcutaneous } \\
\text { injection in a form } \\
\text { of ADSC-enriched } \\
\text { fat }\end{array}$ & $\begin{array}{c}\text { Significant } \\
\text { increase of } \\
\text { surviving fat } \\
\text { volume }\end{array}$ & 2013 & [74] \\
\hline 3 & $\begin{array}{c}\text { Cranio- } \\
\text { Maxillofacial } \\
\text { hard-tissue defects }\end{array}$ & $13(53.23 \pm 10.29)$ & $\begin{array}{l}\text { Autologous, } \\
\text { derived from } \\
\text { abdominal fat }\end{array}$ & $\begin{array}{l}\text { ADSC seeded } \\
\text { resorbable } \\
\text { scaffolds were } \\
\text { implanted }\end{array}$ & $\begin{array}{l}\text { Successful } \\
\text { integration of the } \\
\text { construct in } 10 \text { of } \\
\text { the } 13 \text { cases. }\end{array}$ & 2014 & [75] \\
\hline
\end{tabular}

${ }^{1}$ In this study, age was presented as mean with the range, ${ }^{2}$ beta-tricalcium phosphate (betaTCP).

Although these three studies were classified in this category because they were dealing with craniofacial defects, they can be further classified by the characteristic of ADSCs with which those studies intended to produce therapeutic effects, including the osteogenic differentiation potential and the adipogenic differentiation potential. To be more specific, the osteogenic differentiation potential is for calvarial defects and cranio-maxillofacial hardtissue defects, and the adipogenic differentiation potential is for craniofacial microsomia.

Calvarial defects refer to defects of the skull and are caused by various reasons including but not limited to trauma, infection, congenital malformations, neoplasm, and the surgical removal of tumors [76]. Likewise, cranio-maxillofacial hard-tissue defects can be a result of congenital malformations, traumatic avulsion, tumor resection, or severe infection. Clinical approaches for reconstruction of such defects encompass autografts, allografts, xenografts, or alloplastic grafts. Although the use of autografts is considered to be the gold standard for the reconstruction of bony defects $[77,78]$, they still have limitations such as donor site morbidity, bone resorption, and lack of tissue availability [79-81]. On the other hand, alloplastic grafts have no donor-site morbidity and can be precisely shaped for individualized reconstruction so that they have replaced autografts as the more advanced gold standard for the reconstruction [82]. Nevertheless, they also have limitations such as a lack of ability to integrate and grow with the host bone [83,84].

To achieve proper regeneration, cell delivery to bony defect may be required in addition to the use of a proper scaffold. In general, cell-based therapeutic strategies for bony defects utilize either scaffolds pre-seeded with cells or acellular scaffolds promoting in situ recruitment of autologous cells [85]. Due to the limited quantity issue of BM-MSCs, ADSC s have become an alternative source of adult stem cells that are more easily obtainable in large numbers. Additionally, the osteogenic differentiation potential of ADSCs made them an even more promising candidate for bony defects. 
The very first animal study on the feasibility of using ADSCs for calvarial defects was reported in 2004. In that particular study, it was demonstrated that ADSC seeded in a poly(lactic-co-glycolic acid) (PLGA) scaffold achieved complete bone bridging in a mouse model, and the treatment contributed to the majority (84-99\%) of newly formed bone [86]. Furthermore, the first case report of the use of ADSCs to augment calvarial defects in a 7 -year-old girl came in 2004 as well [87]. In that study, ADSCs with fibrin glue promoted new bone formation and near complete calvarial continuity within three months following the treatment. Slightly larger clinical studies followed some years later, and those studies are covered by this review.

In a study published in 2011, autologous ADSCs $\left(1.5 \times 10^{7}\right.$ cells $)$ derived from abdominal fat were used to augment calvarial defects in four patients [73]. For adjuvant, beta-tricalcium phosphate (betaTCP) granule, a well-known bone substitute material to improve osteogenesis $[88,89]$, was used, and the results indicated satisfactory ossification without complications. In another study published in 2014, it was demonstrated that a composite of abdominal-fat-derived ADSCs seeded on resorbable scaffolds was applied to hard tissue defects of various craniomaxillofacial sites, including the frontal sinus (three cases), the frontal cranium (two cases), the parietal cranium (two cases), the temporal cranium (one case), the mandible chin (one case), the mandible body (two cases), and the nasal septum (two cases). The average number of ADSCs applied was approximately $6.5 \times 10^{6}$ with a range of $2.8 \times 10^{6}$ to $1.6 \times 10^{7}$, and the results indicated that the composites successfully integrated into host tissues in 10 out of 13 cases [75].

Of note, unlike the majority of the OA cases where naive ADSCs were treated without any other adjuvants, those clinical trials for ossification frequently used scaffolds to promote new bone formation. This indicates that, although naive ADSCs have some beneficial effect to augment a bony defect [90], using only naive ADSCs for a bony defect may not be sufficient to produce the desired outcomes. Speaking of adjuvants for ossification, osteoinduction prior to transplantation is known to be effective, especially in treating critical-size defects $[91,92]$. Therefore, future studies on ADSCs, or any type of stem cells for that matter, for a bony defect may focus on finding an optimized combination of adjuvants such as scaffolds and osteoinducing agents. A brief overview on currently available options may help in selecting the ideal osteoinducing agents for future studies.

Although ADSCs have adipogenic, chondrogenic, or osteogenic differentiation potential, each specific lineage has major regulators, and Runx2 and Osterix are such major regulators for osteogenesis $[93,94]$. Moreover, several signaling pathways including bone morphogenetic protein (BMP) [95], Notch [96], Wnt [97], and Hedgehog-signaling [98] are known to regulate osteogenic differentiation, and the Wnt signaling pathway is possibly the most critical since it drives ADSCs away from adipogenic or chondrogenic lineages to a osteogenic lineage by increasing Runx2 and Osterix $[99,100]$. There are also well-known supplementary substances added to the medium to promote osteogenic differentiation of ADSCs such as dexamethasone, beta-glycerophosphate, and ascorbic acid [101]. Dexamethasone has been reported to increase Runx2 activity, Beta-glycerophosphate promotes osteogenesis by being a phosphate source, and ascorbic acid increases production and subsequent secretion of pro-collagen [102].

In addition, pro-osteogenic growth factors such as bone morphogenetic protein (BMP) can be used to promote osteogenesis. Belonging to the transforming growth factor (TGF) family [103], BMP is a well-established pro-osteogenic growth factor [104], and BMPinduced osteogenic differentiation of ADSCs has been reported $[105,106]$. The binding of BMP-2 or -3 to Ser/Thr kinase receptors results in phosphorylation of the Smad1/5/8 complex, which eventually increases the expression of RunX2 and Osterix by recruiting Smad4 to the complex [95]. The effectiveness of BMP in bone repair has been demonstrated in clinical trials $[107,108]$. Lastly, there are also other supplements that may enhance the osteogeneic potential of ADSCs, and they include, but are not limited to, vitamin D3 [109], selenium [110], and alendronate [111]. 
In addition to the above-mentioned biological molecules that regulate the osteogenic differentiation of ADSCs, using meticulously chosen biomaterials as scaffolds to provide mechanical stability and protection may also promote osteogenic differentiation of ADSCs. An appropriate scaffold can simulate the biological signals from extracellular the matrix, and it provides binding sites for cell adhesion as well as space for calcium deposition. To accommodate such requirements, carefully considering the size and interconnection of pores, as well as the stiffness of material (material property), are important. For example, although the size of osteoblasts is in the range of 10-50 $\mu \mathrm{m}$ [112], regeneration of mineralized bone was enhanced with macropores $(100-200 \mu \mathrm{m})$ possibly because the lager pore size allows the infiltration of other cells involved in colonization and vascularization [113]. On the other hand, in contrast to macropores, micropores (pore size $<10 \mu \mathrm{m}$ ) provide a greater surface area for cell adhesion and showed better bone protein adsorption [114].

Therefore, a wide range of materials with various pore sizes are actively being developed and tested $[115,116]$. The frequently reported biomaterials for the bone-regenerating scaffolds include hydroxyapatite (HA) [117], $\beta$-tricalcium phosphate ( $\beta$-TCP) [73], synthetic polymers such as polylactic acid (PLA) [118], and poly lactic-co-glycolic acid (PLGA) [119]. Furthermore, a combination of osteogenic bioactive molecules and biomaterial-based scaffolds has also been tested. For example, a BMP-2 coated PLGA scaffold was applied to a calvarial defect, and the result indicated that the growth-factor-immobilized scaffold increased the osteogenic differentiation of ADSCs [120]. As such, stem cells, bioactive molecules, and scaffolds are three major components of the currently available bone regeneration strategy [121], and finding an ideal combination of these factors can make or break the current bone regeneration approaches. Since ADSCs harvested from patients with ongoing osteoporosis or aging may have a compromised potential for bone formation [122,123], these combinatory approaches will be especially beneficial when such patients undergo autologous ADSC therapy.

Craniofacial microsomia is one of the most common congenital conditions and is associated with anomalies of the jaws, ears, facial soft tissue, orbits, and facial nerve function [124]. Due to such a wide phenotypic spectrum, diagnosis and treatment of craniofacial microsomia is challenging. Often accompanied in craniofacial microsomia, soft tissue deficiency can be repaired with reconstructive techniques such as free flap, dermal fat graft, and structural fat graft.

Also known as free tissue transfer, free flap surgery refers to a transplantation of tissue and its blood supply, which are surgically removed from one part of the body for the purpose of reconstruction. Although the adipofascial free flap is regarded as the best method to provide a large amount of soft tissue for a severe deficiency [125], limitations such as donor-site morbidity and a lengthy procedure still remain. Another well-established approach is a dermal fat graft for moderate and mild deformities. However, a certain degree of resorption and the subsequent need for additional augmentations are the limitations of this procedure [126]. Finally, there is the structural fat grafting that has changed the way various reconstruction-requiring conditions are treated [127,128]. Invented by Sidney Coleman [129], structural fat grafting involves fat harvesting from the abdomen, flanks, thighs, or buttocks; a refinement process; and microinjection (injection of small aliquots). The structural fat grafting can increase the precision of delivery, minimize scarring, and decrease donor-site morbidity, while yielding a greater number of viable adipocytes with more optimal function within fat grafts [130].

The study covered by this review also applied the structural fat grafting on microsomia with modification. The modification was to enrich the fat grafts with additionally isolated ADSCs so that the ADSC content of the graft increased [74]. In fact, ADSC-enriched fat transplantation significantly increased the surviving fat volume in that study, and such results stand to reason considering ADSCs are more tenacious than mature adipocytes, and the surviving ADSCs are the major effector of fat tissue transplantation [131,132]. 
Considering ADSCs can also differentiate into endothelial cells and smooth muscle cells, leading to new blood vessel formation $[133,134]$, such a beneficial effect of ADSCs might be the result of increased neovascularization within the transplanted fat tissue [135]. Additionally, ADSCs are known to secrete pro-angiogenic factors such as VEGF and hepatocyte growth factor (HGF) [136], and therefore, ADSCs may promote angiogenesis of the host tissue and within the graft to improve graft revascularization and subsequent graft survival. Another soluble factor released from ADSCs that may improve fat graft survival is IGF-1. IGF-1 is a known anti-apoptotic factor [137], and it has been demonstrated that sustained release of IGF-1 from ADSCs protected cardiomyocytes from apoptosis following myocardial infarction [138].

Furthermore, IGF-1 is also a potent mitogen for adipocyte differentiation [139], and therefore, ADSCs may prevent apoptosis of the graft, while stimulating preadipocytes' differentiation into mature adipocytes, thus retaining graft volume. Lastly, the most recent mechanistic insight for the role of ADSCs on the survival of fat graft involves the extracellular vesicles (EVs) released from ADSCs [140]. In that particular study, it was demonstrated that ADSC-derived EVs enriched with the let-7 family of miRNAs improved the survival of fat grafts by promoting angiogenesis via the let-7/argonaute 1 (AGO1)/VEGF signaling pathway.

\subsection{Tendon- and Ligament-Related Disorders}

Out of 20 clinical studies covered by this review, 5 studies were on tendon- and ligament-related disorders, namely, 2 studies on lateral epicondylosis and lateral elbow tendinopathy, 2 studies on rotator cuff tears, and 1 study on anterior cruciate ligament (Table 3). 
Table 3. Summary of clinical studies involving the use of isolated hADSCs on arm disorders for the last 10 years.

\begin{tabular}{|c|c|c|c|c|c|c|c|}
\hline & Target Disorder & $\begin{array}{l}\text { No. of Patients Treated } \\
\text { (Age: Mean } \pm \text { SD) }\end{array}$ & ADSC Type & $\begin{array}{c}\text { ADSC } \\
\text { Delivery }\end{array}$ & $\begin{array}{l}\text { Study } \\
\text { Outcome }\end{array}$ & Year & Ref. No. \\
\hline 1 & $\begin{array}{l}\text { Lateral } \\
\text { epicondylosis }\end{array}$ & $12(51.85 \pm 13.86)$ & Allogeneic & $\begin{array}{l}\text { Intratendinous injection } \\
\text { with fibrin glue }\end{array}$ & $\begin{array}{l}\text { Safe and improved elbow pain (VAS } \\
\left.{ }^{1}\right) \text {, performance }\left(\mathrm{MEPI}^{2} \text { ), and }\right. \\
\text { structural defects }\end{array}$ & 2015 & [141] \\
\hline 2 & $\begin{array}{l}\text { chronic lateral } \\
\text { elbow tendinopathy }\end{array}$ & $18\left(46.5 \pm \mathrm{NA}^{3}\right)$ & $\begin{array}{l}\text { Autologous, derived from } \\
\text { periumbilical zone }\end{array}$ & $\begin{array}{l}\text { Percutaneous injection to } \\
\text { the affected elbow }\end{array}$ & $\begin{array}{l}\text { Significantly improved mean VAS } \\
\text { scores for maximum pain score, } \\
\text { QuickDASH }{ }^{4} \text {-Compulsory score, } \\
\text { QuickDASH-Sport score }\end{array}$ & 2021 & [142] \\
\hline 4 & Rotator cuff tears & $11(64.60 \pm 9.60)$ & $\begin{array}{l}\text { Autologous, derived from } \\
\text { either the periumbilical } \\
\text { abdominal area, bilateral } \\
\text { flanks, or medial thigh fat }\end{array}$ & Intra-articular injection & $\begin{array}{l}\text { Significantly higher mean ASES }{ }^{5} \\
\text { total scores without adverse events }\end{array}$ & 2020 & [144] \\
\hline 5 & $\begin{array}{l}\text { Anterior cruciate ligament } \\
\text { reconstruction }\end{array}$ & $20(24.70 \pm 4.70)$ & $\begin{array}{l}\text { Autologous, derived from } \\
\text { abdominal or inner thigh fat }\end{array}$ & $\begin{array}{l}\text { Intra-articular injection, } \\
\text { applied to BTB }{ }^{6} \text { autograft }\end{array}$ & $\begin{array}{l}\text { Although ADSC significantly } \\
\text { improved knee function and } \\
\text { healing/maturation of the graft, it } \\
\text { was not significantly different } \\
\text { compared to the control group }\end{array}$ & 2019 & [145] \\
\hline
\end{tabular}

Assessment Form (ASES); ${ }^{6}$ bone-patellar tendon-bone (BTB). 
Often called the "tennis elbow," lateral epicondylosis is a common painful condition that affects the tendons joining the forearm muscles on the outside of the elbow [146]. Common non-surgical treatment of lateral epicondylosis includes, but not is limited to, physiotherapy [147], injections of corticosteroid [148], extracorporeal shock wave therapy [149], acupuncture [150], topical glyceryl trinitrate [151], botulinum toxin [152], and platelet-rich plasma [153]. Regarding the cell therapy for lateral epicondylosis, it was surprising that only a handful of studies had been conducted to date. Except the two studies subjected to this review, there were only five clinical studies that involved cell therapy on lateral epicondylosis, and they have used tenocytes, tenocyte-like cells, bone marrow aspirates, and allogeneic ADSCs, respectively [154-158]. It was also interesting to notice that tenocytes or tenocyte-like cells were more frequently used than MSCs [155,157].

Considering lateral epicondylosis involves inflammation and/or tearing of the tendons joining the forearm muscles on the outside of the elbow [76], it seems to be intuitively logical to prefer tenocyte or tenocyte-like cells over classical stem cells such as BM-MSCs. Since the one study used bone marrow aspirate rather than isolated BM-MSCs [158], the studies covered by this review are the only studies that examined the effect of isolated stem cells. In the study published in 2015, either $10^{6}$ or $10^{7}$ allogeneic ADSCs were used, and the results showed that there was no significant AEs and VAS score that progressively decreased, indicating improved pain management. Furthermore, the MEPI performance score significantly increased, demonstrating that ADSC therapy was safe and effective for treating lateral epicondylosis [141].

Another study where 18 tennis players were treated with approximately $8 \times 10^{6}$ autologous ADSCs for recalcitrant lateral elbow tendinopathy indicated that ADSC therapy significantly improved clinical parameters readily at one month following injection and structural repair of the origin of common extensor tendon at six months after injection [142], without any joint effusion or skin hypersensitivity reactions that had been observed in the previous similar study where allogeneic ADSCs were used [141].

Another tendon-related disorder treated with ADSCs is rotator cuff tears. The rotator cuff refers to a structured tendinous insertions of muscles for stabilizing the glenohumeral joint, and rotator cuff disorder is the most common condition of the shoulder in the aged population $[159,160]$. Rotator cuff tears can be caused by either traumatic or degenerative reasons. Traumatic tears occur literally due to significant trauma to the rotator cuff, while degenerative tears are more common and multifactorial in that both extrinsic factors such as the anterior part of the cuff abutting against the coracoacromial arch during forward elevation of the shoulder [161] and intrinsic factors like excess levels of reactive oxygen species (ROS) damaging tendons [162] gradually lead to a full-thickness tear.

Rotator cuff tears are often treated with surgical options to increase function and decrease pain, and new materials and surgical techniques to improve the outcomes of the surgical repair have been utilized to meet such ends [163]. However, the regeneration of the fibro-cartilaginous transition zone between the rotator cuff and the bone has not been satisfactory [164] with a persistently high failure rate of the repair [165]. Thus, the efforts to improve the biological environment around the damaged cuff using growth factors as well as stem cells came into play $[166,167]$.

Regarding the use of stem cells for rotator cuff tears, it was demonstrated that rotatorcuff-derived MSCs have higher myogenic potential compared to BM-MSCs [168], and tenocyte-derived stem cells from tendons have been isolated and characterized [169]. However, the very first clinical study of stem cells' effect on rotator cuff utilized mononuclear stem cells from bone marrow aspirate, which resulted in better functional outcomes than would usually be expected without stem cell adjuvant [170]. Similarly, the study used additional autologous ADSCs injection (a mean of $4.46 \times 10^{6}$ cells in $2 \mathrm{~mL}$ of fibrin glue) during arthroscopic rotator cuff repair, which also demonstrated that using ADSCs as the adjuvant improved the structural outcome possibly by providing an adequate biological environment around the cuff [143]. Furthermore, not only as an adjuvant but also as an independent therapeutic, the effect of ADSCs in the treatment of rotator cuffs has been 
demonstrated in a very recent study [144]. In that study, a single injection of an average of $11.4 \times 10^{6}$ autologous ADSCs was used to treat symptomatic, partial-thickness rotator cuff tears, and the treatment improved shoulder function without AEs suggesting a potential of ADSCs as a substitute for corticosteroids commonly used for short-term pain relief [171]. Altogether, those studies indicated that ADSC-based cell therapy represents a feasible option in order to improve rotator cuff regeneration.

As to the possible underlying mechanisms of MSCs for treating tendinopathy, although initial therapeutic strategy might have been targeted tenogenic differentiation of delivered MSCs, it seems that the therapeutic effects of MSCs are mainly achieved by interacting with the tendon resident cells [172]. It has been reported that co-culturing tendon cells and BM-MSCs up-regulated the expression of tendon-related genes such as scleraxis and tenomodulin, collagens, decorine, and tenascin, leading to significant tendon ECM deposition [173,174], which suggests that BM-MSC may enhance the tenogenic capacities of tendon-derived stem cells and tendon stem/progenitor cells. Similar to the case of BMMSCs, ADSCs also have demonstrated that they communicate with tendon cells to increase the expression of tendon-related genes $[175,176]$. Furthermore, a previous study that examined the effect of ADSCs on the tendon niche showed that ADSCs helped to preserve the native architecture of tendon tissue with early increased collagenolytic activity of matrix metalloproteinases (MMPs) [177]. Considering the deposition of ECM increased in ADSC and a human tendon-derived cell co-culture system [176], it may be possible that ADSCs exert a beneficial effect on tendon regeneration by modulating the microenvironment of the tendon niche.

Finally, an anterior cruciate ligament (ACL) tear is the disorder that had been subjected to ADSC-based cell therapy. With the posterior cruciate ligament, the anterior cruciate ligament helps stabilize a knee joint [178]. An anterior cruciate ligament tear is one of the most common knee injuries, and it is estimated that approximately 80,000 to 100,000 anterior cruciate ligament repairs are performed each year in the United States [179]. The majority of anterior cruciate ligament tears are caused by a non-contact mechanism such as sudden directional change making the knee rotate inward [180]. Due to greatly advanced surgical techniques [181], anterior cruciate ligament reconstruction became a gold standard for anterior cruciate ligament tears [182]. However, only less than a half of patients achieve full recovery [183], and patellar tendon grafts used for reconstruction are different from natural anterior cruciate ligaments [184]. Such limitations of anterior cruciate ligament reconstruction necessitated exploration of other therapeutic options including the use of growth factors, platelet-rich plasma, and stem cells.

A number of different types of stem cells have been examined for their potential as alternative therapeutics for anterior cruciate ligament tears to date. First of all, MSCs have been most widely investigated possibly because they are capable of ligamentogenic differentiation with proper growth factors [185-187]. Another type of MSC examined for their potential in treating anterior cruciate ligament tears is synovium-derived mesenchymal stem cells (SMSCs) [188]. Furthermore, it has been demonstrated that they have higher proliferation and differentiation potentials than MSCs derived from other tissues [189], suggesting SMSCs can be a feasible candidate for alternative therapeutics. Not surprisingly, stem cells derived from anterior cruciate ligaments were examined for their potential as well, and the studies indicated that anterior cruciate ligament-derived stem cells have characteristics very similar to those of BM-MSC, suggesting they could be a viable source of stem cells for anterior cruciate ligament repair [190,191].

Regarding the potential use of ADSCS for the treatment of anterior cruciate ligament tears, in vitro studies demonstrated that human ADSCs failed to stimulate anterior cruciate ligament fibroblast proliferation and collagen production [192], which had been observed for porcine ADSCs [193], making the therapeutic beneficial of ADSCs in treating anterior cruciate ligament tears uncertain. In fact, one study covered by this review also demonstrated that $1.8 \times 10^{7}$ ADSCs loaded in bone-patellar tendon-bone (BTB) graft produced no statistically significant improvement compared to a control group (without ADSC admin- 
istration). Nevertheless, there are only a handful of studies that exist, so further studies are needed to fully evaluate the potential of ADSCs as alternative therapeutics for anterior cruciate ligament tears.

Although how ADSCs enhance ligament repair is not completely elucidated, mechanical signals from the host tissue may significantly contribute to the observed beneficial effect of ADSCs. A previous study examined the effect of co-culturing with ACL cells, and mechanical stress on MSC indicated that the combination of regulatory signals from ACL cells and mechanical stress enhanced selective differentiation of MSCs toward ligament cells by demonstrating increased typical ACL cell markers such as collagen type I and III and tenascin in MSCs following co-culturing with ACL cells in the presence of mechanical stress [194]. Therefore, it is reasonable to speculate that mechanical signals from host tissue following cell transplantation may stimulate cell-surface stretch receptors and adhesion sites, resulting in increased synthesis and secretion of key ligament ECM components [195].

\subsection{Spine Disorders}

Out of 20 clinical studies covered by this review, 2 studies were on spine disorders, namely, one on degenerative spondylolisthesis and the other on chronic discongenic low back pain (Table 4 ).

Table 4. Summary of clinical studies involving the use of isolated hADSCs on spine disorders for the last 10 years.

\begin{tabular}{|c|c|c|c|c|c|c|c|}
\hline & Target Disorder & $\begin{array}{c}\text { No. of Patients } \\
\text { Treated } \\
\text { (Age: Mean } \pm \text { SD) }\end{array}$ & ADSC Type & $\begin{array}{c}\text { ADSC } \\
\text { Delivery }\end{array}$ & $\begin{array}{l}\text { Study } \\
\text { Outcome }\end{array}$ & Year & Ref. No. \\
\hline 1 & $\begin{array}{c}\text { Degenerative } \\
\text { spondylolisthesis } \\
\text { (TLIF) }{ }^{1}\end{array}$ & $3(48.70 \pm 14.30)$ & $\begin{array}{c}\text { Autologous, } \\
\text { derived from } \\
\text { abdominal fat }\end{array}$ & $\begin{array}{c}\text { ADSC seeded } \\
\text { DBM }^{2} \text { was } \\
\text { implanted into the } \\
\text { disc space }\end{array}$ & $\begin{array}{l}\text { Grad } 3 \text { fusion, } \\
\text { VAS and ODI } \\
\text { improved }\end{array}$ & 2017 & [196] \\
\hline 2 & $\begin{array}{l}\text { Chronic discogenic } \\
\text { low back pain }\end{array}$ & $10(43.50 \pm 10.16)$ & $\begin{array}{c}\text { Autologous, } \\
\text { derived from } \\
\text { abdominal fat }\end{array}$ & $\begin{array}{c}\text { Percutaneous } \\
\text { injection of ADSC } \\
\text { in combination } \\
\text { with HA }^{4} \\
\text { derivatives }\end{array}$ & $\begin{array}{c}\text { Safe and } \\
\text { tolerable } \\
\text { without no } \\
\text { adverse events. }\end{array}$ & 2017 & [197] \\
\hline
\end{tabular}

${ }^{1}$ Transforaminal lumbar interbody fusion (TLIF), ${ }^{2}$ demineralized bone matrix (DBM), ${ }^{3}$ Oswestry disability index (ODI), ${ }^{4}$ hyaruronic acid (HA).

Spinal disorder refers to a condition impairing the backbone, and the associated pain poses a major medical and socioeconomic problem due to its high prevalence in the general population [198]. Degenerative spondylolisthesis is defined as a condition where one vertebral body slips forward on top of another one below without rupture of the posterior arc [199], and more than 10\% of the population in the United States suffers from this condition [200]. For patients who are symptomatic, non-operative conservative treatment options includes anti-inflammatory medications such as non-steroidal anti-inflammatory drugs (NSAIDs) and narcotic analgesics [201], physical therapy [202], and epidural steroid injections [203]. On the other hand, fusion surgery has been proven to be effective for patients who do not respond well to non-operative management [204]. However, fusion surgery that frequently involves the use of autologous iliac crest bone grafts (AICBG) [205] accompanies a risk of complications such as donor site pain, infection, hematoma, and meralgia paresthetica [206,207].

In an effort to overcome such limitations, alternative options such as new bone substitutes [208] and stem-cell-based approaches have been explored. Studies that explored the potential of MSCs for spinal fusion have demonstrated that the use of MSCs produced outcomes comparable to those of iliac crest grafts in terms of histology and mechanical properties [209,210]. Regarding clinical trials involving application of ADSCs to degenerative spondylolisthesis, one study covered by this review reported that the use of 3D graft made of autologous ADSCs in patients receiving minimally invasive transforaminal 
lumbar interbody fusion (MI-TLIF) resulted in significant improvement in the VAS score and the ODI and achievement of grade 3 fusion without donor site complications [196]. Although only one study did not guarantee the clinical benefit of using ADSCs for degenerative spondylolisthesis so that further studies are required, a very recent study where a combination of BM-MSC and allogeneic graft achieved a higher rate of posterior spinal fusion and radiographic complete response without significant AEs [211] also suggests the potential of ADSCs, or stem cells in general, as alternative therapeutics for degenerative spondylolisthesis.

Chronic low back pain is one of the leading causes of disability and one of the major clinical and socioeconomic global health burdens [212]. The term discogenic back pain refers to back pain caused by internal structural change of the lumbar intervertebral disc (IVD) without herniation, anatomical deformity, or other alternate clear causes of pain and disability [213]. Quite similar to the case of degenerative spondylolisthesis, common non-operative modalities for chronic discongenic low back pain include drug therapy using NSAIDs [214] and opioids [215], physical rehabilitation theary [216], epidural injection [217], and percutaneous intradiscal therapies to alter the internal mechanics of the disc with heat, radiofrequency, or injection of various chemicals [218]. As for surgical treatment options, interbody fusion [219], prosthesis replacement [220], and dynamic fixation system [221] have been utilized for chronic discogenic low back pain.

Regenerative approaches for chronic low back pain involve the use of PRP [222,223], chondrocytes [224], and stem cells. The feasibility and safety of MSC-based cell therapy for chronic back pain has also been examined, and clinical benefits such as analgesic effects and functional improvement were demonstrated $[197,225,226]$. Those studies also include the study using ADSCs, and according to that particular study, a single intradiscal injection of hyaluronic acid (HA) derivatives and an autologous ADSC $\left(2\right.$ or $4 \times 10^{7}$ cell/disc) mixture significantly improved VAS, ODI, and SF-36 scores without AEs in patients with chronic discogenic low back pain [197], demonstrating the safety and tolerability of ADSC-based cell therapy as well as its promising clinical efficacy.

The IVD is located between the vertebral bodies of the spinal column, and the nucleus pulposus (NP, nucleus) comprises the inner gelatinous structure [227]. The deterioration of NP architecture, which can be characterized by the change of gelatinous, hydrated ECM into a more fibrous tissue due to aging or pathologic trauma, is the main cause of intervertebral disc degeneration (IDD) [228], and IDD is a major cause of back pain. Therefore, restoring the adequate NP architecture may relieve the pain, and this is what MSC-based cell therapy targets. In other words, MSCs may differentiate into mature cells, support resident cell activity by paracrine mechanism, and/or recruit local progenitor cells to promote endogenous repair of the degenerated IVD [229]. As supporting evidence for such speculation, first, multiple studies have reported NP-cell-like differentiation of MSCs [230-232], and one recent study indicated that the IVD-transplanted autologous BM-MSCs survived in the host IVD tissues up to eight months [233].

Regarding the MSC supporting of resident cells, it has been demonstrated that coculturing MSCs with NP cells increased cell proliferation and ECM production of NP cells $[234,235]$, and the exosome-mediated paracrine mechanism was found to contribute to this resident-cell-supporting effect of MSCs [236]. Additionally, immunomodulation by MSCs may also contribute to the regenerative effect of MSCs in IDD. As for the inflammatory response during IDD, IVD resident cells and immune cells release several proinflammatory cytokines including, but not limited to, $\mathrm{IL}-\mathrm{lb}$, tumor necrosis factor alpha $(\mathrm{TNF} \alpha)$, interferon-c, and prostaglandin E2 causing ECM breakdown, neoangiogenesis, and the stimulaton of additional cytokines [237-239]. Since such inflammatory stimuli can increase cell apoptosis and neurogenic differentiation of NP-MSCs, which may contribute to IVD reinnervation and the development of chronic LBP [240], MSCs that are known to produce anti-inflammatory cytokines, anticatabolic mediators, and growth factors even under IDD-like conditions [241,242] may help to create a microenvironment favoring IVD regeneration. 


\section{Conclusions}

MSDs are now the second most common cause of years lived with disability (YLD) in the world [243]. Therefore, an effective long-term solution for MSDs would relieve pain and agony for a significant portion of the population as well as reduce the related socioeconomic costs for the healthcare system. Regenerative therapies, including stem cell-based therapy, are non-surgical conservative interventions that will likely be preferred over conventional invasive surgical approaches once their safety, reliability, and efficacy are confirmed in humans. The use of ADSC-based therapy in the regeneration of musculoskeletal tissue is relatively young but dynamic. Although the current literature regarding the clinical use of ADSCs in MSDs is still limited, the preliminary results of initial clinical trials both in humans and in animals indicate that it can be safe and effective for bone defects, cartilage regeneration, and tendinopathies (Figure 2). Nevertheless, to harness the full therapeutic potential of ADSCs, further basic studies are desired, as are longer-term safety studies and more randomized larger-scale controlled trials to examine the safety and efficacy of ADSC-based therapy for MSDs.

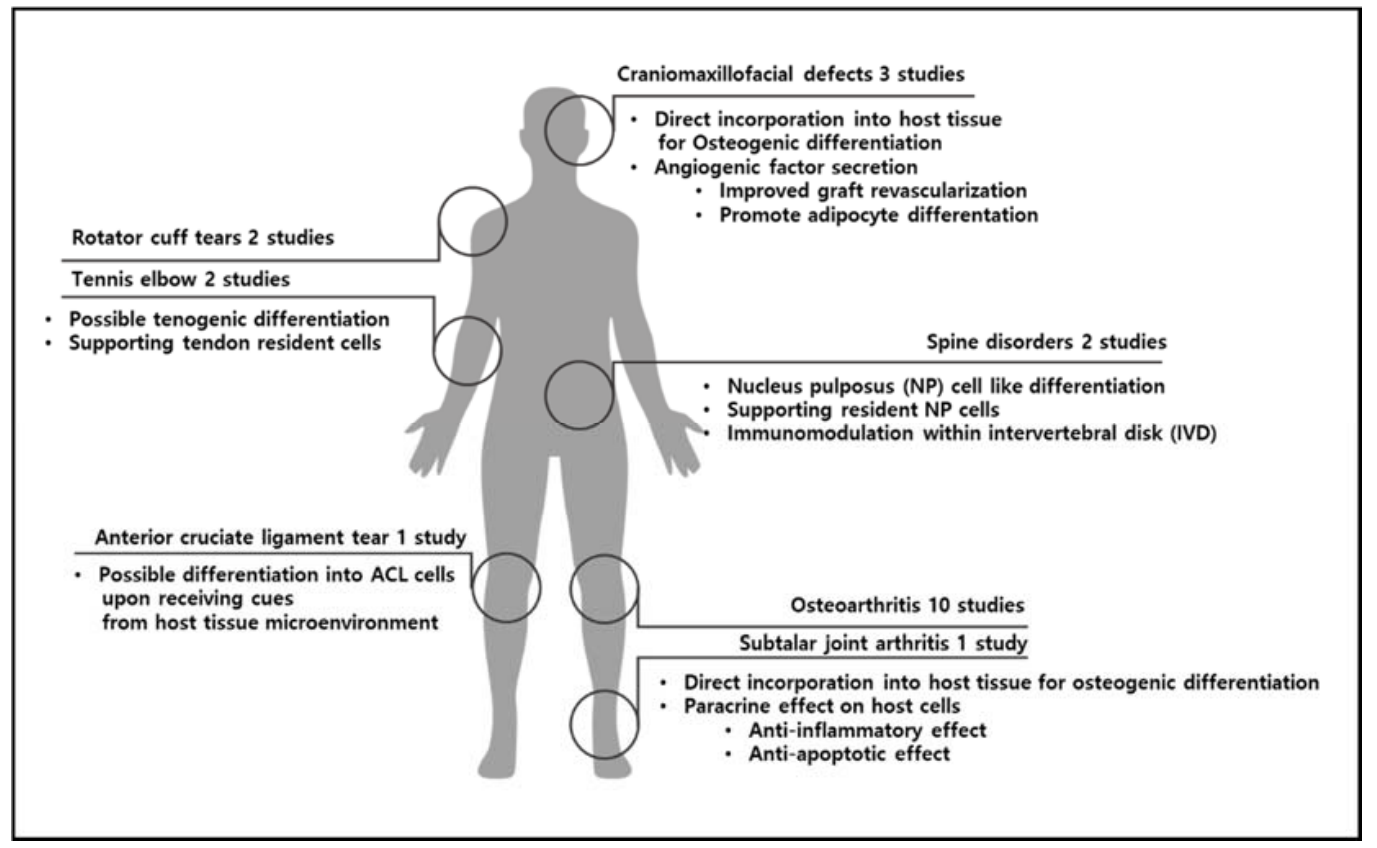

Figure 2. Summary of MSDs covered by this review and possible underlying mechanisms with which delivered ADSCs produce regenerative effects.

Author Contributions: Conceptualization, S.L. (Seahyoung Lee) and K.-C.H.; writing-original draft preparation, S.L. (Seahyoung Lee), B.-W.S. and I.-K.K.; writing-review and editing, D.-S.C. and I.-K.K.; supervision, K.-C.H.; project administration, I.-K.K.; funding acquisition, K.-C.H.; writingrevision and editing, S.L. (Seahyoung Lee), S.L. (Soyeon Lim), and S.W.K. All authors have read and agreed to the published version of the manuscript.

Funding: This research was funded by the Ministry of Health \& Welfare, Republic of Korea, grant number HI18C0661.

Institutional Review Board Statement: Not applicable.

Informed Consent Statement: Not applicable.

Data Availability Statement: Not applicable.

Conflicts of Interest: The authors declare no conflict of interest. 


\section{References}

1. Zakrzewski, W.; Dobrzynski, M.; Szymonowicz, M.; Rybak, Z. Stem cells: Past, present, and future. Stem Cell Res. Ther. 2019, 10, 68. [CrossRef] [PubMed]

2. King, N.M.; Perrin, J. Ethical issues in stem cell research and therapy. Stem Cell Res. Ther. 2014, 5, 85. [CrossRef]

3. Friedenstein, A.J.; Chailakhjan, R.K.; Lalykina, K.S. The development of fibroblast colonies in monolayer cultures of guinea-pig bone marrow and spleen cells. Cell Tissue Kinet. 1970, 3, 393-403. [CrossRef]

4. Murphy, M.B.; Moncivais, K.; Caplan, A.I. Mesenchymal stem cells: Environmentally responsive therapeutics for regenerative medicine. Exp. Mol. Med. 2013, 45, e54. [CrossRef]

5. Mastrolia, I.; Foppiani, E.M.; Murgia, A.; Candini, O.; Samarelli, A.V.; Grisendi, G.; Veronesi, E.; Horwitz, E.M.; Dominici, M. Challenges in Clinical Development of Mesenchymal Stromal/Stem Cells: Concise Review. Stem Cells Transl. Med. 2019, 8 , 1135-1148. [CrossRef]

6. Hass, R.; Kasper, C.; Bohm, S.; Jacobs, R. Different populations and sources of human mesenchymal stem cells (MSC): A comparison of adult and neonatal tissue-derived MSC. Cell Commun. Signal. 2011, 9, 12. [CrossRef]

7. Kuhbier, J.W.; Weyand, B.; Radtke, C.; Vogt, P.M.; Kasper, C.; Reimers, K. Isolation, characterization, differentiation, and application of adipose-derived stem cells. Adv. Biochem. Eng. Biotechnol. 2010, 123, 55-105.

8. Zuk, P.A.; Zhu, M.; Ashjian, P.; De Ugarte, D.A.; Huang, J.I.; Mizuno, H.; Alfonso, Z.C.; Fraser, J.K.; Benhaim, P.; Hedrick, M.H. Human adipose tissue is a source of multipotent stem cells. Mol. Biol. Cell 2002, 13, 4279-4295. [CrossRef]

9. Tsuji, W.; Rubin, J.P.; Marra, K.G. Adipose-derived stem cells: Implications in tissue regeneration. World J. Stem Cells 2014, 6, 312-321. [CrossRef] [PubMed]

10. Safiri, S.; Kolahi, A.A.; Cross, M.; Carson-Chahhoud, K.; Almasi-Hashiani, A.; Kaufman, J.; Mansournia, M.A.; Sepidarkish, M.; Ashrafi-Asgarabad, A.; Hoy, D.; et al. Global, regional, and national burden of other musculoskeletal disorders 1990-2017: Results from the Global Burden of Disease Study 2017. Rheumatology 2021, 60, 855-865. [CrossRef] [PubMed]

11. Ishimura, D.; Yamamoto, N.; Tajima, K.; Ohno, A.; Yamamoto, Y.; Washimi, O.; Yamada, H. Differentiation of adipose-derived stromal vascular fraction culture cells into chondrocytes using the method of cell sorting with a mesenchymal stem cell marker. Tohoku J. Exp. Med. 2008, 216, 149-156. [CrossRef]

12. Koh, Y.G.; Choi, Y.J. Infrapatellar fat pad-derived mesenchymal stem cell therapy for knee osteoarthritis. Knee 2012, 19, 902-907. [CrossRef]

13. Jo, C.H.; Lee, Y.G.; Shin, W.H.; Kim, H.; Chai, J.W.; Jeong, E.C.; Kim, J.E.; Shim, H.; Shin, J.S.; Shin, I.S.; et al. Intra-articular injection of mesenchymal stem cells for the treatment of osteoarthritis of the knee: A proof-of-concept clinical trial. Stem Cells 2014, 32, 1254-1266. [CrossRef]

14. Koh, Y.G.; Kwon, O.R.; Kim, Y.S.; Choi, Y.J.; Tak, D.H. Adipose-Derived Mesenchymal Stem Cells with Microfracture Versus Microfracture Alone: 2-Year Follow-up of a Prospective Randomized Trial. Arthroscopy 2016, 32, 97-109. [CrossRef]

15. Pers, Y.M.; Rackwitz, L.; Ferreira, R.; Pullig, O.; Delfour, C.; Barry, F.; Sensebe, L.; Casteilla, L.; Fleury, S.; Bourin, P.; et al. Adipose Mesenchymal Stromal Cell-Based Therapy for Severe Osteoarthritis of the Knee: A Phase I Dose-Escalation Trial. Stem Cells Transl. Med. 2016, 5, 847-856. [CrossRef] [PubMed]

16. Álvaro-Gracia, J.M.; Jover, J.A.; García-Vicuña, R.; Carreño, L.; Alonso, A.; Marsal, S.; Blanco, F.; Martínez-Taboada, V.M.; Taylor, P.; Martín-Martín, C.; et al. Intravenous administration of expanded allogeneic adipose-derived mesenchymal stem cells in refractory rheumatoid arthritis (Cx611): Results of a multicentre, dose escalation, randomised, single-blind, placebo-controlled phase Ib/IIa clinical trial. Ann. Rheum. Dis. 2017, 76, 196-202. [CrossRef] [PubMed]

17. Song, Y.; Du, H.; Dai, C.; Zhang, L.; Li, S.; Hunter, D.J.; Lu, L.; Bao, C. Human adipose-derived mesenchymal stem cells for osteoarthritis: A pilot study with long-term follow-up and repeated injections. Regen. Med. 2018, 13, 295-307. [CrossRef] [PubMed]

18. Freitag, J.; Bates, D.; Wickham, J.; Shah, K.; Huguenin, L.; Tenen, A.; Paterson, K.; Boyd, R. Adipose-derived mesenchymal stem cell therapy in the treatment of knee osteoarthritis: A randomized controlled trial. Regen. Med. 2019, 14, 213-230. [CrossRef]

19. Lee, W.S.; Kim, H.J.; Kim, K.I.; Kim, G.B.; Jin, W. Intra-Articular Injection of Autologous Adipose Tissue-Derived Mesenchymal Stem Cells for the Treatment of Knee Osteoarthritis: A Phase IIb, Randomized, Placebo-Controlled Clinical Trial. Stem Cells Transl. Med. 2019, 8, 504-511. [CrossRef] [PubMed]

20. Lu, L.; Dai, C.; Zhang, Z.; Du, H.; Li, S.; Ye, P.; Fu, Q.; Zhang, L.; Wu, X.; Dong, Y.; et al. Treatment of knee osteoarthritis with intra-articular injection of autologous adipose-derived mesenchymal progenitor cells: A prospective, randomized, double-blind, active-controlled, phase IIb clinical trial. Stem Cell Res. Ther. 2019, 10, 143. [CrossRef]

21. Myerson, C.L.; Myerson, M.S.; Coetzee, J.C.; Stone McGaver, R.; Giveans, M.R. Subtalar Arthrodesis with Use of Adipose-Derived Cellular Bone Matrix Compared with Autologous Bone Graft: A Multicenter, Randomized Controlled Trial. J. Bone Jt. Surg. Am. 2019, 101, 1904-1911. [CrossRef]

22. Zhao, X.; Ruan, J.; Tang, H.; Li, J.; Shi, Y.; Li, M.; Li, S.; Xu, C.; Lu, Q.; Dai, C. Multi-compositional MRI evaluation of repair cartilage in knee osteoarthritis with treatment of allogeneic human adipose-derived mesenchymal progenitor cells. Stem Cell Res. Ther. 2019, 10, 308. [CrossRef] [PubMed]

23. Primorac, D.; Molnar, V.; Rod, E.; Jelec, Z.; Cukelj, F.; Matisic, V.; Vrdoljak, T.; Hudetz, D.; Hajsok, H.; Boric, I. Knee Osteoarthritis: A Review of Pathogenesis and State-Of-The-Art Non-Operative Therapeutic Considerations. Genes 2020, 11, 854. [CrossRef] [PubMed] 
24. van den Berg, W.B. The role of cytokines and growth factors in cartilage destruction in osteoarthritis and rheumatoid arthritis. Z. Rheumatol. 1999, 58, 136-141. [CrossRef] [PubMed]

25. Nelson, A.E.; Allen, K.D.; Golightly, Y.M.; Goode, A.P.; Jordan, J.M. A systematic review of recommendations and guidelines for the management of osteoarthritis: The chronic osteoarthritis management initiative of the U.S. bone and joint initiative. Semin. Arthritis Rheum. 2014, 43, 701-712. [CrossRef]

26. Zhang, W.; Nuki, G.; Moskowitz, R.W.; Abramson, S.; Altman, R.D.; Arden, N.K.; Bierma-Zeinstra, S.; Brandt, K.D.; Croft, P.; Doherty, M.; et al. OARSI recommendations for the management of hip and knee osteoarthritis: Part III: Changes in evidence following systematic cumulative update of research published through January 2009. Osteoarthr. Cartil. 2010, 18, 476-499. [CrossRef] [PubMed]

27. Jevotovsky, D.S.; Alfonso, A.R.; Einhorn, T.A.; Chiu, E.S. Osteoarthritis and stem cell therapy in humans: A systematic review. Osteoarthr. Cartil. 2018, 26, 711-729. [CrossRef] [PubMed]

28. Martin, J.R.; Jennings, J.M.; Dennis, D.A. Morbid Obesity and Total Knee Arthroplasty: A Growing Problem. J. Am. Acad. Orthop. Surg. 2017, 25, 188-194. [CrossRef] [PubMed]

29. Patel, S.; Dhillon, M.S.; Aggarwal, S.; Marwaha, N.; Jain, A. Treatment with platelet-rich plasma is more effective than placebo for knee osteoarthritis: A prospective, double-blind, randomized trial. Am. J. Sports Med. 2013, 41, 356-364. [CrossRef]

30. Wang, C.T.; Lin, J.; Chang, C.J.; Lin, Y.T.; Hou, S.M. Therapeutic effects of hyaluronic acid on osteoarthritis of the knee. A meta-analysis of randomized controlled trials. J. Bone Jt. Surg. Am. 2004, 86, 538-545. [CrossRef] [PubMed]

31. Chen, F.H.; Rousche, K.T.; Tuan, R.S. Technology Insight: Adult stem cells in cartilage regeneration and tissue engineering. Nat. Clin. Pract. Rheumatol. 2006, 2, 373-382. [CrossRef]

32. Freitag, J.; Bates, D.; Boyd, R.; Shah, K.; Barnard, A.; Huguenin, L.; Tenen, A. Mesenchymal stem cell therapy in the treatment of osteoarthritis: Reparative pathways, safety and efficacy-A review. BMC Musculoskelet. Disord. 2016, 17, 230. [CrossRef]

33. Barry, F.; Murphy, M. Mesenchymal stem cells in joint disease and repair. Nat. Rev. Rheumatol. 2013, 9, 584-594. [CrossRef] [PubMed]

34. Vezina Audette, R.; Lavoie-Lamoureux, A.; Lavoie, J.P.; Laverty, S. Inflammatory stimuli differentially modulate the transcription of paracrine signaling molecules of equine bone marrow multipotent mesenchymal stromal cells. Osteoarthr. Cartil. 2013, 21, 1116-1124. [CrossRef] [PubMed]

35. Vega, A.; Martin-Ferrero, M.A.; Del Canto, F.; Alberca, M.; Garcia, V.; Munar, A.; Orozco, L.; Soler, R.; Fuertes, J.J.; Huguet, M.; et al. Treatment of Knee Osteoarthritis with Allogeneic Bone Marrow Mesenchymal Stem Cells: A Randomized Controlled Trial. Transplantation 2015, 99, 1681-1690. [CrossRef] [PubMed]

36. Wakitani, S.; Imoto, K.; Yamamoto, T.; Saito, M.; Murata, N.; Yoneda, M. Human autologous culture expanded bone marrow mesenchymal cell transplantation for repair of cartilage defects in osteoarthritic knees. Osteoarthr. Cartil. 2002, 10, 199-206. [CrossRef]

37. Prockop, D.J. Repair of tissues by adult stem/progenitor cells (MSCs): Controversies, myths, and changing paradigms. Mol. Ther 2009, 17, 939-946. [CrossRef]

38. Black, L.L.; Gaynor, J.; Gahring, D.; Adams, C.; Aron, D.; Harman, S.; Gingerich, D.A.; Harman, R. Effect of adipose-derived mesenchymal stem and regenerative cells on lameness in dogs with chronic osteoarthritis of the coxofemoral joints: A randomized, double-blinded, multicenter, controlled trial. Vet. Ther. 2007, 8, 272-284.

39. Frisbie, D.D.; Kisiday, J.D.; Kawcak, C.E.; Werpy, N.M.; McIlwraith, C.W. Evaluation of adipose-derived stromal vascular fraction or bone marrow-derived mesenchymal stem cells for treatment of osteoarthritis. J. Orthop. Res. 2009, 27, 1675-1680. [CrossRef]

40. Lee, J.M.; Im, G.I. SOX trio-co-transduced adipose stem cells in fibrin gel to enhance cartilage repair and delay the progression of osteoarthritis in the rat. Biomaterials 2012, 33, 2016-2024. [CrossRef]

41. Pak, J. Regeneration of human bones in hip osteonecrosis and human cartilage in knee osteoarthritis with autologous adiposetissue-derived stem cells: A case series. J. Med. Case Rep. 2011, 5, 296. [CrossRef] [PubMed]

42. Lalu, M.M.; McIntyre, L.; Pugliese, C.; Fergusson, D.; Winston, B.W.; Marshall, J.C.; Granton, J.; Stewart, D.J.; Canadian Critical Care Trials, G. Safety of cell therapy with mesenchymal stromal cells (SafeCell): A systematic review and meta-analysis of clinical trials. PLoS ONE 2012, 7, e47559. [CrossRef] [PubMed]

43. Lysholm, J.; Gillquist, J. Evaluation of knee ligament surgery results with special emphasis on use of a scoring scale. Am. J. Sports Med. 1982, 10, 150-154. [CrossRef] [PubMed]

44. Tegner, Y.; Lysholm, J. Rating systems in the evaluation of knee ligament injuries. Clin. Orthop. Relat. Res. 1985, 198, 43-49. [CrossRef]

45. Ornetti, P.; Dougados, M.; Paternotte, S.; Logeart, I.; Gossec, L. Validation of a numerical rating scale to assess functional impairment in hip and knee osteoarthritis: Comparison with the WOMAC function scale. Ann. Rheum. Dis. 2011, 70, 740-746. [CrossRef] [PubMed]

46. Toh, W.S.; Brittberg, M.; Farr, J.; Foldager, C.B.; Gomoll, A.H.; Hui, J.H.; Richardson, J.B.; Roberts, S.; Spector, M. Cellular senescence in aging and osteoarthritis. Acta Orthop. 2016, 87, 6-14. [CrossRef]

47. Haslauer, C.M.; Elsaid, K.A.; Fleming, B.C.; Proffen, B.L.; Johnson, V.M.; Murray, M.M. Loss of extracellular matrix from articular cartilage is mediated by the synovium and ligament after anterior cruciate ligament injury. Osteoarthr. Cartil. 2013, 21, 1950-1957. [CrossRef] [PubMed] 
48. Zwolanek, D.; Satue, M.; Proell, V.; Godoy, J.R.; Odorfer, K.I.; Flicker, M.; Hoffmann, S.C.; Rulicke, T.; Erben, R.G. Tracking mesenchymal stem cell contributions to regeneration in an immunocompetent cartilage regeneration model. JCI Insight 2017, 2, e87322. [CrossRef]

49. Mizuno, K.; Muneta, T.; Morito, T.; Ichinose, S.; Koga, H.; Nimura, A.; Mochizuki, T.; Sekiya, I. Exogenous synovial stem cells adhere to defect of meniscus and differentiate into cartilage cells. J. Med. Dent. Sci. 2008, 55, 101-111.

50. Park, Y.B.; Ha, C.W.; Kim, J.A.; Han, W.J.; Rhim, J.H.; Lee, H.J.; Kim, K.J.; Park, Y.G.; Chung, J.Y. Single-stage cell-based cartilage repair in a rabbit model: Cell tracking and in vivo chondrogenesis of human umbilical cord blood-derived mesenchymal stem cells and hyaluronic acid hydrogel composite. Osteoarthr. Cartil. 2017, 25, 570-580. [CrossRef]

51. de Windt, T.S.; Vonk, L.A.; Slaper-Cortenbach, I.C.M.; Nizak, R.; van Rijen, M.H.P.; Saris, D.B.F. Allogeneic MSCs and Recycled Autologous Chondrons Mixed in a One-Stage Cartilage Cell Transplantion: A First-in-Man Trial in 35 Patients. Stem Cells 2017, 35, 1984-1993. [CrossRef]

52. Ferreira, J.R.; Teixeira, G.Q.; Santos, S.G.; Barbosa, M.A.; Almeida-Porada, G.; Goncalves, R.M. Mesenchymal Stromal Cell Secretome: Influencing Therapeutic Potential by Cellular Pre-conditioning. Front. Immunol. 2018, 9, 2837. [CrossRef]

53. Dinescu, S.; Dobranici, A.; Tecucianu, R.; Selaru, A.; Balahura, R.; Ignat, S.; Costache, M. Exosomes as Part of the Human Adipose-Derived Stem Cells Secretome- Opening New Perspectives for Cell-Free Regenerative Applications. Adv. Exp. Med. Biol. 2021, 1312, 139-163. [PubMed]

54. Kapur, S.K.; Katz, A.J. Review of the adipose derived stem cell secretome. Biochimie 2013, 95, 2222-2228. [CrossRef] [PubMed]

55. Gardner, O.F.; Fahy, N.; Alini, M.; Stoddart, M.J. Differences in human mesenchymal stem cell secretomes during chondrogenic induction. Eur. Cells Mater. 2016, 31, 221-235. [CrossRef] [PubMed]

56. Bermudez, M.A.; Sendon-Lago, J.; Seoane, S.; Eiro, N.; Gonzalez, F.; Saa, J.; Vizoso, F.; Perez-Fernandez, R. Anti-inflammatory effect of conditioned medium from human uterine cervical stem cells in uveitis. Exp. Eye Res. 2016, 149, 84-92. [CrossRef]

57. Park, B.S.; Kim, W.S.; Choi, J.S.; Kim, H.K.; Won, J.H.; Ohkubo, F.; Fukuoka, H. Hair growth stimulated by conditioned medium of adipose-derived stem cells is enhanced by hypoxia: Evidence of increased growth factor secretion. Biomed. Res. 2010, 31, 27-34. [CrossRef]

58. Kinnaird, T.; Stabile, E.; Burnett, M.S.; Lee, C.W.; Barr, S.; Fuchs, S.; Epstein, S.E. Marrow-derived stromal cells express genes encoding a broad spectrum of arteriogenic cytokines and promote in vitro and in vivo arteriogenesis through paracrine mechanisms. Circ. Res. 2004, 94, 678-685. [CrossRef]

59. Lee, M.J.; Kim, J.; Lee, K.I.; Shin, J.M.; Chae, J.I.; Chung, H.M. Enhancement of wound healing by secretory factors of endothelial precursor cells derived from human embryonic stem cells. Cytotherapy 2011, 13, 165-178. [CrossRef]

60. Yi, T.; Song, S.U. Immunomodulatory properties of mesenchymal stem cells and their therapeutic applications. Arch. Pharm. Res. 2012, 35, 213-221. [CrossRef]

61. Cantinieaux, D.; Quertainmont, R.; Blacher, S.; Rossi, L.; Wanet, T.; Noel, A.; Brook, G.; Schoenen, J.; Franzen, R. Conditioned medium from bone marrow-derived mesenchymal stem cells improves recovery after spinal cord injury in rats: An original strategy to avoid cell transplantation. PLoS ONE 2013, 8, e69515. [CrossRef]

62. Mirabella, T.; Cilli, M.; Carlone, S.; Cancedda, R.; Gentili, C. Amniotic liquid derived stem cells as reservoir of secreted angiogenic factors capable of stimulating neo-arteriogenesis in an ischemic model. Biomaterials 2011, 32, 3689-3699. [CrossRef]

63. See, F.; Seki, T.; Psaltis, P.J.; Sondermeijer, H.P.; Gronthos, S.; Zannettino, A.C.; Govaert, K.M.; Schuster, M.D.; Kurlansky, P.A.; Kelly, D.J.; et al. Therapeutic effects of human STRO-3-selected mesenchymal precursor cells and their soluble factors in experimental myocardial ischemia. J. Cell. Mol. Med. 2011, 15, 2117-2129. [CrossRef]

64. Epstein, S.E.; Luger, D.; Lipinski, M.J. Paracrine-Mediated Systemic Anti-Inflammatory Activity of Intravenously Administered Mesenchymal Stem Cells: A Transformative Strategy for Cardiac Stem Cell Therapeutics. Circ. Res. 2017, 121, 1044-1046. [CrossRef]

65. Carelli, S.; Colli, M.; Vinci, V.; Caviggioli, F.; Klinger, M.; Gorio, A. Mechanical Activation of Adipose Tissue and Derived Mesenchymal Stem Cells: Novel Anti-Inflammatory Properties. Int. J. Mol. Sci. 2018, 19, 267. [CrossRef]

66. Tan, K.; Zhu, H.; Zhang, J.; Ouyang, W.; Tang, J.; Zhang, Y.; Qiu, L.; Liu, X.; Ding, Z.; Deng, X. CD73 Expression on Mesenchymal Stem Cells Dictates the Reparative Properties via Its Anti-Inflammatory Activity. Stem Cells Int. 2019, 2019, 8717694. [CrossRef] [PubMed]

67. Davies, L.C.; Blain, E.J.; Gilbert, S.J.; Caterson, B.; Duance, V.C. The potential of IGF-1 and TGFbeta1 for promoting "adult" articular cartilage repair: An in vitro study. Tissue Eng. Part A 2008, 14, 1251-1261. [CrossRef]

68. Yaeger, P.C.; Masi, T.L.; de Ortiz, J.L.; Binette, F.; Tubo, R.; McPherson, J.M. Synergistic action of transforming growth factor-beta and insulin-like growth factor-I induces expression of type II collagen and aggrecan genes in adult human articular chondrocytes. Exp. Cell Res. 1997, 237, 318-325. [CrossRef] [PubMed]

69. Kooijman, R. Regulation of apoptosis by insulin-like growth factor (IGF)-I. Cytokine Growth Factor Rev. 2006, 17, 305-323. [CrossRef] [PubMed]

70. Montaseri, A.; Busch, F.; Mobasheri, A.; Buhrmann, C.; Aldinger, C.; Rad, J.S.; Shakibaei, M. IGF-1 and PDGF-bb suppress IL-1beta-induced cartilage degradation through down-regulation of NF-kappaB signaling: Involvement of Src/PI-3K/AKT pathway. PLoS ONE 2011, 6, e28663. [CrossRef] 
71. Li, B.; Zhang, H.; Zeng, M.; He, W.; Li, M.; Huang, X.; Deng, D.Y.; Wu, J. Bone marrow mesenchymal stem cells protect alveolar macrophages from lipopolysaccharide-induced apoptosis partially by inhibiting the Wnt/beta-catenin pathway. Cell Biol. Int. 2015, 39, 192-200. [CrossRef]

72. Maumus, M.; Manferdini, C.; Toupet, K.; Peyrafitte, J.A.; Ferreira, R.; Facchini, A.; Gabusi, E.; Bourin, P.; Jorgensen, C.; Lisignoli, G.; et al. Adipose mesenchymal stem cells protect chondrocytes from degeneration associated with osteoarthritis. Stem Cell Res. 2013, 11, 834-844. [CrossRef]

73. Thesleff, T.; Lehtimäki, K.; Niskakangas, T.; Mannerström, B.; Miettinen, S.; Suuronen, R.; Öhman, J. Cranioplasty with adiposederived stem cells and biomaterial: A novel method for cranial reconstruction. Neurosurgery 2011, 68, 1535-1540. [CrossRef]

74. Tanikawa, D.Y.S.; Aguena, M.; Bueno, D.F.; Passos-Bueno, M.R.; Alonso, N. Fat grafts supplemented with adipose-derived stromal cells in the rehabilitation of patients with craniofacial microsomia. Plast. Reconstr. Surg. 2013, 132, 141-152. [CrossRef]

75. Sándor, G.K.; Numminen, J.; Wolff, J.; Thesleff, T.; Miettinen, A.; Tuovinen, V.J.; Mannerström, B.; Patrikoski, M.; Seppänen, R.; Miettinen, S.; et al. Adipose stem cells used to reconstruct 13 cases with cranio-maxillofacial hard-tissue defects. Stem Cells Transl. Med. 2014, 3, 530-540. [CrossRef]

76. Jaskolka, M.S.; Olavarria, G. Reconstruction of skull defects. Atlas Oral Maxillofac. Surg. Clin. N. Am. 2010, 18, 139-149. [CrossRef] [PubMed]

77. Spetzger, U.; Vougioukas, V.; Schipper, J. Materials and techniques for osseous skull reconstruction. Minim. Invasive Ther. Allied Technol. 2010, 19, 110-121. [CrossRef] [PubMed]

78. Bianchi, B.; Ferri, A.; Ferrari, S.; Leporati, M.; Copelli, C.; Ferri, T.; Sesenna, E. Mandibular resection and reconstruction in the management of extensive ameloblastoma. J. Oral Maxillofac. Surg. 2013, 71, 528-537. [CrossRef]

79. Dimitriou, R.; Mataliotakis, G.I.; Angoules, A.G.; Kanakaris, N.K.; Giannoudis, P.V. Complications following autologous bone graft harvesting from the iliac crest and using the RIA: A systematic review. Injury 2011, 42 (Suppl. 2), S3-S15. [CrossRef] [PubMed]

80. Rocque, B.G.; Amancherla, K.; Lew, S.M.; Lam, S. Outcomes of cranioplasty following decompressive craniectomy in the pediatric population. J. Neurosurg. Pediatr. 2013, 12, 120-125. [CrossRef] [PubMed]

81. Knothe, U.R.; Dolejs, S.; Matthew Miller, R.; Knothe Tate, M.L. Effects of mechanical loading patterns, bone graft, and proximity to periosteum on bone defect healing. J. Biomech. 2010, 43, 2728-2737. [CrossRef]

82. Vincent, A.; Sokoya, M.; Shokri, T.; Gordin, E.; Inman, J.C.; Manolidis, S.; Ducic, Y. Management of Skull Fractures and Calvarial Defects. Facial Plast. Surg. 2019, 35, 651-656. [CrossRef]

83. Parthasarathy, J. 3D modeling, custom implants and its future perspectives in craniofacial surgery. Ann. Maxillofac. Surg. 2014, 4, 9-18. [CrossRef]

84. Yuan, J.; Cao, Y.; Liu, W. Biomimetic scaffolds: Implications for craniofacial regeneration. J. Craniofac. Surg. 2012, 23, 294-297. [CrossRef] [PubMed]

85. Yoon, E.; Dhar, S.; Chun, D.E.; Gharibjanian, N.A.; Evans, G.R. In vivo osteogenic potential of human adipose-derived stem cells/poly lactide-co-glycolic acid constructs for bone regeneration in a rat critical-sized calvarial defect model. Tissue Eng. 2007, 13, 619-627. [CrossRef] [PubMed]

86. Cowan, C.M.; Shi, Y.Y.; Aalami, O.O.; Chou, Y.F.; Mari, C.; Thomas, R.; Quarto, N.; Contag, C.H.; Wu, B.; Longaker, M.T. Adipose-derived adult stromal cells heal critical-size mouse calvarial defects. Nat. Biotechnol. 2004, 22, 560-567. [CrossRef] [PubMed]

87. Lendeckel, S.; Jodicke, A.; Christophis, P.; Heidinger, K.; Wolff, J.; Fraser, J.K.; Hedrick, M.H.; Berthold, L.; Howaldt, H.P. Autologous stem cells (adipose) and fibrin glue used to treat widespread traumatic calvarial defects: Case report. J. Craniomaxillofac. Surg. 2004, 32, 370-373. [CrossRef] [PubMed]

88. Galois, L.; Mainard, D.; Delagoutte, J.P. Beta-tricalcium phosphate ceramic as a bone substitute in orthopaedic surgery. Int. Orthop. 2002, 26, 109-115. [PubMed]

89. Gao, P.; Zhang, H.; Liu, Y.; Fan, B.; Li, X.; Xiao, X.; Lan, P.; Li, M.; Geng, L.; Liu, D.; et al. Beta-tricalcium phosphate granules improve osteogenesis in vitro and establish innovative osteo-regenerators for bone tissue engineering in vivo. Sci. Rep. 2016, 6, 23367. [CrossRef]

90. Jeon, O.; Rhie, J.W.; Kwon, I.K.; Kim, J.H.; Kim, B.S.; Lee, S.H. In vivo bone formation following transplantation of human adipose-derived stromal cells that are not differentiated osteogenically. Tissue Eng. Part A 2008, 14, 1285-1294. [CrossRef]

91. Di Bella, C.; Farlie, P.; Penington, A.J. Bone regeneration in a rabbit critical-sized skull defect using autologous adipose-derived cells. Tissue Eng. Part A 2008, 14, 483-490. [CrossRef]

92. Dudas, J.R.; Marra, K.G.; Cooper, G.M.; Penascino, V.M.; Mooney, M.P.; Jiang, S.; Rubin, J.P.; Losee, J.E. The osteogenic potential of adipose-derived stem cells for the repair of rabbit calvarial defects. Ann. Plast. Surg. 2006, 56, 543-548. [CrossRef]

93. Komori, T. Regulation of osteoblast differentiation by transcription factors. J. Cell. Biochem. 2006, 99, 1233-1239. [CrossRef] [PubMed]

94. Nakashima, K.; Zhou, X.; Kunkel, G.; Zhang, Z.; Deng, J.M.; Behringer, R.R.; de Crombrugghe, B. The novel zinc finger-containing transcription factor osterix is required for osteoblast differentiation and bone formation. Cell 2002, 108, 17-29. [CrossRef]

95. Rahman, M.S.; Akhtar, N.; Jamil, H.M.; Banik, R.S.; Asaduzzaman, S.M. TGF-beta/BMP signaling and other molecular events: Regulation of osteoblastogenesis and bone formation. Bone Res. 2015, 3, 15005. [CrossRef] [PubMed] 
96. Long, F. Building strong bones: Molecular regulation of the osteoblast lineage. Nat. Rev. Mol. Cell Biol. 2011, 13, 27-38. [CrossRef] [PubMed]

97. Shafaei, H.; Kalarestaghi, H. Adipose-derived stem cells: An appropriate selection for osteogenic differentiation. J. Cell. Physiol. 2020, 235, 8371-8386. [CrossRef]

98. Yang, J.; Andre, P.; Ye, L.; Yang, Y.Z. The Hedgehog signalling pathway in bone formation. Int. J. Oral Sci. 2015, 7, 73-79. [CrossRef]

99. Senarath-Yapa, K.; McArdle, A.; Renda, A.; Longaker, M.T.; Quarto, N. Adipose-derived stem cells: A review of signaling networks governing cell fate and regenerative potential in the context of craniofacial and long bone skeletal repair. Int. J. Mol. Sci. 2014, 15, 9314-9330. [CrossRef]

100. Houschyar, K.S.; Tapking, C.; Borrelli, M.R.; Popp, D.; Duscher, D.; Maan, Z.N.; Chelliah, M.P.; Li, J.; Harati, K.; Wallner, C.; et al. Wnt Pathway in Bone Repair and Regeneration-What Do We Know So Far. Front. Cell Dev. Biol. 2018, 6, 170. [CrossRef]

101. Langenbach, F.; Handschel, J. Effects of dexamethasone, ascorbic acid and beta-glycerophosphate on the osteogenic differentiation of stem cells in vitro. Stem Cell Res. Ther. 2013, 4, 117. [CrossRef]

102. Park, J.B. The effects of dexamethasone, ascorbic acid, and beta-glycerophosphate on osteoblastic differentiation by regulating estrogen receptor and osteopontin expression. J. Surg. Res. 2012, 173, 99-104. [CrossRef]

103. Wu, M.; Chen, G.; Li, Y.P. TGF-beta and BMP signaling in osteoblast, skeletal development, and bone formation, homeostasis and disease. Bone Res. 2016, 4, 16009. [CrossRef]

104. Lieberman, J.R.; Daluiski, A.; Einhorn, T.A. The role of growth factors in the repair of bone. Biology and clinical applications. J. Bone Jt. Surg. Am. 2002, 84, 1032-1044. [CrossRef] [PubMed]

105. Fan, J.; Park, H.; Tan, S.; Lee, M. Enhanced osteogenesis of adipose derived stem cells with Noggin suppression and delivery of BMP-2. PLOS ONE 2013, 8, e72474. [CrossRef]

106. Chen, L.; Lu, X.; Li, S.; Sun, Q.; Li, W.; Song, D. Sustained delivery of BMP-2 and platelet-rich plasma-released growth factors contributes to osteogenesis of human adipose-derived stem cells. Orthopedics 2012, 35, e1402-e1409. [CrossRef]

107. Aro, H.T.; Govender, S.; Patel, A.D.; Hernigou, P.; Perera de Gregorio, A.; Popescu, G.I.; Golden, J.D.; Christensen, J.; Valentin, A. Recombinant human bone morphogenetic protein-2: A randomized trial in open tibial fractures treated with reamed nail fixation. J. Bone Jt. Surg. Am. 2011, 93, 801-808. [CrossRef]

108. Katayama, Y.; Matsuyama, Y.; Yoshihara, H.; Sakai, Y.; Nakamura, H.; Imagama, S.; Ito, Z.; Wakao, N.; Kamiya, M.; Yukawa, Y.; et al. Clinical and radiographic outcomes of posterolateral lumbar spine fusion in humans using recombinant human bone morphogenetic protein-2: An average five-year follow-up study. Int. Orthop. 2009, 33, 1061-1067. [CrossRef]

109. Jing, W.; Xiong, Z.; Cai, X.; Huang, Y.; Li, X.; Yang, X.; Liu, L.; Tang, W.; Lin, Y.; Tian, W. Effects of gamma-secretase inhibition on the proliferation and vitamin $\mathrm{D}(3)$ induced osteogenesis in adipose derived stem cells. Biochem. Biophys. Res. Commun. 2010, 392, 442-447. [CrossRef]

110. Zakhireh, S.; Adibkia, K.; Beygi-Khosrowshahi, Y.; Barzegar-Jalali, M. Osteogenesis Promotion of Selenium-Doped Hydroxyapatite for Application as Bone Scaffold. Biol. Trace Elem. Res. 2021, 199, 1802-1811. [CrossRef] [PubMed]

111. Wang, C.Z.; Chen, S.M.; Chen, C.H.; Wang, C.K.; Wang, G.J.; Chang, J.K.; Ho, M.L. The effect of the local delivery of alendronate on human adipose-derived stem cell-based bone regeneration. Biomaterials 2010, 31, 8674-8683. [CrossRef]

112. Sugawara, Y.; Kamioka, H.; Honjo, T.; Tezuka, K.; Takano-Yamamoto, T. Three-dimensional reconstruction of chick calvarial osteocytes and their cell processes using confocal microscopy. Bone 2005, 36, 877-883. [CrossRef]

113. Iviglia, G.; Kargozar, S.; Baino, F. Biomaterials, Current Strategies, and Novel Nano-Technological Approaches for Periodontal Regeneration. J. Funct. Biomater. 2019, 10, 3. [CrossRef]

114. Morejon, L.; Delgado, J.A.; Antunes Ribeiro, A.; Varella de Oliveira, M.; Mendizabal, E.; Garcia, I.; Alfonso, A.; Poh, P.; van Griensven, M.; Balmayor, E.R. Development, Characterization and In Vitro Biological Properties of Scaffolds Fabricated From Calcium Phosphate Nanoparticles. Int. J. Mol. Sci. 2019, 20, 1790. [CrossRef] [PubMed]

115. Chen, G.; Kawazoe, N. Porous Scaffolds for Regeneration of Cartilage, Bone and Osteochondral Tissue. Adv. Exp. Med. Biol. 2018, 1058, 171-191.

116. Storti, G.; Scioli, M.G.; Kim, B.S.; Orlandi, A.; Cervelli, V. Adipose-Derived Stem Cells in Bone Tissue Engineering: Useful Tools with New Applications. Stem Cells Int. 2019, 2019, 3673857. [CrossRef] [PubMed]

117. Prosecka, E.; Rampichova, M.; Litvinec, A.; Tonar, Z.; Kralickova, M.; Vojtova, L.; Kochova, P.; Plencner, M.; Buzgo, M.; Mickova, A.; et al. Collagen/hydroxyapatite scaffold enriched with polycaprolactone nanofibers, thrombocyte-rich solution and mesenchymal stem cells promotes regeneration in large bone defect in vivo. J. Biomed. Mater. Res. A 2015, 103, 671-682. [CrossRef] [PubMed]

118. Castillo-Dali, G.; Velazquez-Cayon, R.; Serrera-Figallo, M.A.; Rodriguez-Gonzalez-Elipe, A.; Gutierrez-Perez, J.L.; Torres-Lagares, D. Importance of Poly(lactic-co-glycolic acid) in Scaffolds for Guided Bone Regeneration: A Focused Review. J. Oral Implantol. 2015, 41, e152-e157. [CrossRef] [PubMed]

119. Fernandes, J.S.; Reis, R.L.; Pires, R.A. Wetspun poly-L-(lactic acid)-borosilicate bioactive glass scaffolds for guided bone regeneration. Mater. Sci. Eng. C Mater. Biol. Appl. 2017, 71, 252-259. [CrossRef]

120. Ko, E.; Yang, K.; Shin, J.; Cho, S.W. Polydopamine-assisted osteoinductive peptide immobilization of polymer scaffolds for enhanced bone regeneration by human adipose-derived stem cells. Biomacromolecules 2013, 14, 3202-3213. [CrossRef] 
121. Ho-Shui-Ling, A.; Bolander, J.; Rustom, L.E.; Johnson, A.W.; Luyten, F.P.; Picart, C. Bone regeneration strategies: Engineered scaffolds, bioactive molecules and stem cells current stage and future perspectives. Biomaterials 2018, 180, 143-162. [CrossRef]

122. Kornicka, K.; Marycz, K.; Tomaszewski, K.A.; Maredziak, M.; Smieszek, A. The Effect of Age on Osteogenic and Adipogenic Differentiation Potential of Human Adipose Derived Stromal Stem Cells (hASCs) and the Impact of Stress Factors in the Course of the Differentiation Process. Oxid. Med. Cell. Longev. 2015, 2015, 309169. [CrossRef]

123. Patrikoski, M.; Mannerstrom, B.; Miettinen, S. Perspectives for Clinical Translation of Adipose Stromal/Stem Cells. Stem Cells Int. 2019, 2019, 5858247. [CrossRef]

124. Birgfeld, C.B.; Heike, C. Craniofacial microsomia. Semin. Plast. Surg. 2012, 26, 91-104. [CrossRef] [PubMed]

125. Longaker, M.T.; Siebert, J.W. Microsurgical correction of facial contour in congenital craniofacial malformations: The marriage of hard and soft tissue. Plast. Reconstr. Surg. 1996, 98, 942-950. [CrossRef] [PubMed]

126. Mordick, T.G., 2nd; Larossa, D.; Whitaker, L. Soft-tissue reconstruction of the face: A comparison of dermal-fat grafting and vascularized tissue transfer. Ann. Plast. Surg. 1992, 29, 390-396. [CrossRef]

127. Clauser, L.C.; Tieghi, R.; Galie, M.; Carinci, F. Structural fat grafting: Facial volumetric restoration in complex reconstructive surgery. J. Craniofac. Surg. 2011, 22, 1695-1701. [CrossRef] [PubMed]

128. Coleman, S.R. Structural fat grafting: More than a permanent filler. Plast. Reconstr. Surg. 2006, 118 (Suppl. 3), 108S-120S. [CrossRef]

129. Coleman, S.R. Structural fat grafting. Aesthet. Surg. J. 1998, 18, 386-388. [CrossRef]

130. Pu, L.L.Q.; Coleman, S.R.; Cui, X.; Ferguson, R.E.H., Jr.; Vasconez, H.C. Autologous fat grafts harvested and refined by the Coleman technique: A comparative study. Plast. Reconstr. Surg. 2008, 122, 932-937. [CrossRef] [PubMed]

131. Rigotti, G.; Marchi, A.; Galie, M.; Baroni, G.; Benati, D.; Krampera, M.; Pasini, A.; Sbarbati, A. Clinical treatment of radiotherapy tissue damage by lipoaspirate transplant: A healing process mediated by adipose-derived adult stem cells. Plast. Reconstr. Surg. 2007, 119, 1409-1422. [CrossRef]

132. von Heimburg, D.; Hemmrich, K.; Haydarlioglu, S.; Staiger, H.; Pallua, N. Comparison of viable cell yield from excised versus aspirated adipose tissue. Cells Tissues Organs 2004, 178, 87-92. [CrossRef]

133. Planat-Benard, V.; Silvestre, J.S.; Cousin, B.; Andre, M.; Nibbelink, M.; Tamarat, R.; Clergue, M.; Manneville, C.; Saillan-Barreau, C.; Duriez, M.; et al. Plasticity of human adipose lineage cells toward endothelial cells: Physiological and therapeutic perspectives. Circulation 2004, 109, 656-663. [CrossRef]

134. Miranville, A.; Heeschen, C.; Sengenes, C.; Curat, C.A.; Busse, R.; Bouloumie, A. Improvement of postnatal neovascularization by human adipose tissue-derived stem cells. Circulation 2004, 110, 349-355. [CrossRef]

135. Zhu, M.; Zhou, Z.; Chen, Y.; Schreiber, R.; Ransom, J.T.; Fraser, J.K.; Hedrick, M.H.; Pinkernell, K.; Kuo, H.C. Supplementation of fat grafts with adipose-derived regenerative cells improves long-term graft retention. Ann. Plast. Surg. 2010, 64, 222-228. [CrossRef]

136. Rehman, J.; Traktuev, D.; Li, J.; Merfeld-Clauss, S.; Temm-Grove, C.J.; Bovenkerk, J.E.; Pell, C.L.; Johnstone, B.H.; Considine, R.V.; March, K.L. Secretion of angiogenic and antiapoptotic factors by human adipose stromal cells. Circulation 2004, 109, 1292-1298. [CrossRef]

137. Zhang, M.; Liu, J.; Li, M.; Zhang, S.; Lu, Y.; Liang, Y.; Zhao, K.; Li, Y. Insulin-like growth factor 1/insulin-like growth factor 1 receptor signaling protects against cell apoptosis through the PI3K/AKT pathway in glioblastoma cells. Exp. Ther. Med. 2018, 16, 1477-1482. [CrossRef] [PubMed]

138. Bagno, L.L.; Carvalho, D.; Mesquita, F.; Louzada, R.A.; Andrade, B.; Kasai-Brunswick, T.H.; Lago, V.M.; Suhet, G.; Cipitelli, D.; Werneck-de-Castro, J.P.; et al. Sustained IGF-1 Secretion by Adipose-Derived Stem Cells Improves Infarcted Heart Function. Cell Transplant. 2016, 25, 1609-1622. [CrossRef] [PubMed]

139. Christoffersen, C.T.; Tornqvist, H.; Vlahos, C.J.; Bucchini, D.; Jami, J.; De Meyts, P.; Joshi, R.L. Insulin and insulin-like growth factor-I receptor mediated differentiation of 3T3-F442A cells into adipocytes: Effect of PI 3-kinase inhibition. Biochem. Biophys. Res. Commun. 1998, 246, 426-430. [CrossRef] [PubMed]

140. Zhu, Y.; Zhang, J.; Hu, X.; Wang, Z.; Wu, S.; Yi, Y. Extracellular vesicles derived from human adipose-derived stem cells promote the exogenous angiogenesis of fat grafts via the let-7/AGO1/VEGF signalling pathway. Sci. Rep. 2020, 10, 5313. [CrossRef]

141. Lee, S.Y.; Kim, W.; Lim, C.; Chung, S.G. Treatment of Lateral Epicondylosis by Using Allogeneic Adipose-Derived Mesenchymal Stem Cells: A Pilot Study. Stem Cells 2015, 33, 2995-3005. [CrossRef]

142. Khoury, M.; Tabben, M.; Rolon, A.U.; Levi, L.; Chamari, K.; D’Hooghe, P. Promising improvement of chronic lateral elbow tendinopathy by using adipose derived mesenchymal stromal cells: A pilot study. J. Exp. Orthop. 2021, 8, 6. [CrossRef]

143. Kim, Y.S.; Sung, C.H.; Chung, S.H.; Kwak, S.J.; Koh, Y.G. Does an Injection of Adipose-Derived Mesenchymal Stem Cells Loaded in Fibrin Glue Influence Rotator Cuff Repair Outcomes? A Clinical and Magnetic Resonance Imaging Study. Am. J. Sports Med. 2017, 45, 2010-2018. [CrossRef]

144. Hurd, J.L.; Facile, T.R.; Weiss, J.; Hayes, M.; Hayes, M.; Furia, J.P.; Maffulli, N.; Winnier, G.E.; Alt, C.; Schmitz, C.; et al. Safety and efficacy of treating symptomatic, partial-thickness rotator cuff tears with fresh, uncultured, unmodified, autologous adiposederived regenerative cells (UA-ADRCs) isolated at the point of care: A prospective, randomized, controlled first-in-human pilot study. J. Orthop. Surg. Res. 2020, 15, 122. 
145. Alentorn-Geli, E.; Seijas, R.; Martínez-De la Torre, A.; Cuscó, X.; Steinbacher, G.; Álvarez-Díaz, P.; Barastegui, D.; Navarro, J.; Serra-Renom, J.M.; Nishishinya, B.; et al. Effects of autologous adipose-derived regenerative stem cells administered at the time of anterior cruciate ligament reconstruction on knee function and graft healing. J. Orthop. Surg. 2019, 27, 2309499019867580. [CrossRef] [PubMed]

146. Verhaar, J.A. Tennis elbow. Anatomical, epidemiological and therapeutic aspects. Int. Orthop. 1994, 18, 263-267. [PubMed]

147. Malliaras, P.; Maffulli, N.; Garau, G. Eccentric training programmes in the management of lateral elbow tendinopathy. Disabil. Rehabil. 2008, 30, 1590-1596. [CrossRef] [PubMed]

148. Wolf, J.M.; Ozer, K.; Scott, F.; Gordon, M.J.; Williams, A.E. Comparison of autologous blood, corticosteroid, and saline injection in the treatment of lateral epicondylitis: A prospective, randomized, controlled multicenter study. J. Hand Surg. Am. 2011, 36, 1269-1272. [CrossRef]

149. Wong, C.W.; Ng, E.Y.; Fung, P.W.; Mok, K.M.; Yung, P.S.; Chan, K.M. Comparison of treatment effects on lateral epicondylitis between acupuncture and extracorporeal shockwave therapy. Asia Pac. J. Sports Med. Arthrosc. Rehabil. Technol. 2017, 7, 21-26. [CrossRef] [PubMed]

150. Bostrom, K.; Maehlum, S.; Cvancarova Smastuen, M.; Storheim, K. Clinical comparative effectiveness of acupuncture versus manual therapy treatment of lateral epicondylitis: Feasibility randomized clinical trial. Pilot Feasibility Stud. 2019, 5, 110. [CrossRef]

151. Ozden, R.; Uruc, V.; Dogramaci, Y.; Kalaci, A.; Yengil, E. Management of tennis elbow with topical glyceryl trinitrate. Acta Orthop. Traumatol. Turc. 2014, 48, 175-180. [CrossRef]

152. Creuze, A.; Petit, H.; de Seze, M. Short-Term Effect of Low-Dose, Electromyography-Guided Botulinum Toxin A Injection in the Treatment of Chronic Lateral Epicondylar Tendinopathy: A Randomized, Double-Blinded Study. J. Bone Jt. Surg. Am. 2018, 100, 818-826. [CrossRef]

153. Mi, B.; Liu, G.; Zhou, W.; Lv, H.; Liu, Y.; Wu, Q.; Liu, J. Platelet rich plasma versus steroid on lateral epicondylitis: Meta-analysis of randomized clinical trials. Physician Sportsmed. 2017, 45, 97-104. [CrossRef]

154. Freitag, J.; Shah, K.; Wickham, J.; Tenen, A. Effect of autologous adipose-derived mesenchymal stem cell therapy in combination with autologous platelet-rich plasma in the treatment of elbow tendinopathy. BMJ Case Rep. 2020, 13, e234592. [CrossRef]

155. Wang, A.; Breidahl, W.; Mackie, K.E.; Lin, Z.; Qin, A.; Chen, J.; Zheng, M.H. Autologous tenocyte injection for the treatment of severe, chronic resistant lateral epicondylitis: A pilot study. Am. J. Sports Med. 2013, 41, 2925-2932. [CrossRef] [PubMed]

156. Wang, A.; Mackie, K.; Breidahl, W.; Wang, T.; Zheng, M.H. Evidence for the Durability of Autologous Tenocyte Injection for Treatment of Chronic Resistant Lateral Epicondylitis: Mean 4.5-Year Clinical Follow-up. Am. J. Sports Med. 2015, 43, 1775-1783. [CrossRef]

157. Connell, D.; Datir, A.; Alyas, F.; Curtis, M. Treatment of lateral epicondylitis using skin-derived tenocyte-like cells. Br. J. Sports Med. 2009, 43, 293-298. [CrossRef] [PubMed]

158. Singh, A.; Gangwar, D.S.; Singh, S. Bone marrow injection: A novel treatment for tennis elbow. J. Nat. Sci. Biol. Med. 2014, 5, 389-391. [CrossRef] [PubMed]

159. Gomoll, A.H.; Katz, J.N.; Warner, J.J.; Millett, P.J. Rotator cuff disorders: Recognition and management among patients with shoulder pain. Arthritis Rheum. 2004, 50, 3751-3761. [CrossRef] [PubMed]

160. Riley, G. The pathogenesis of tendinopathy. A molecular perspective. Rheumatology 2004, 43, 131-142. [CrossRef] [PubMed]

161. Neer, C.S., 2nd. Anterior acromioplasty for the chronic impingement syndrome in the shoulder: A preliminary report. J. Bone Jt. Surg. Am. 1972, 54, 41-50. [CrossRef]

162. Yuan, J.; Murrell, G.A.; Trickett, A.; Landtmeters, M.; Knoops, B.; Wang, M.X. Overexpression of antioxidant enzyme peroxiredoxin 5 protects human tendon cells against apoptosis and loss of cellular function during oxidative stress. Biochim. Biophys. Acta 2004, 1693, 37-45. [CrossRef]

163. Duquin, T.R.; Buyea, C.; Bisson, L.J. Which method of rotator cuff repair leads to the highest rate of structural healing? A systematic review. Am. J. Sports Med. 2010, 38, 835-841. [CrossRef] [PubMed]

164. Galatz, L.M.; Sandell, L.J.; Rothermich, S.Y.; Das, R.; Mastny, A.; Havlioglu, N.; Silva, M.J.; Thomopoulos, S. Characteristics of the rat supraspinatus tendon during tendon-to-bone healing after acute injury. J. Orthop. Res. 2006, 24, 541-550. [CrossRef] [PubMed]

165. Tashjian, R.Z.; Hollins, A.M.; Kim, H.M.; Teefey, S.A.; Middleton, W.D.; Steger-May, K.; Galatz, L.M.; Yamaguchi, K. Factors affecting healing rates after arthroscopic double-row rotator cuff repair. Am. J. Sports Med. 2010, 38, 2435-2442. [CrossRef] [PubMed]

166. Rodeo, S.A. Biologic augmentation of rotator cuff tendon repair. J. Shoulder Elbow Surg. 2007, 16 (Suppl. 5), S191-S197. [CrossRef] [PubMed]

167. Isaac, C.; Gharaibeh, B.; Witt, M.; Wright, V.J.; Huard, J. Biologic approaches to enhance rotator cuff healing after injury. J. Shoulder Elbow Surg. 2012, 21, 181-190. [CrossRef] [PubMed]

168. Tsai, C.C.; Huang, T.F.; Ma, H.L.; Chiang, E.R.; Hung, S.C. Isolation of mesenchymal stem cells from shoulder rotator cuff: A potential source for muscle and tendon repair. Cell Transplant. 2013, 22, 413-422. [CrossRef] [PubMed]

169. Randelli, P.; Conforti, E.; Piccoli, M.; Ragone, V.; Creo, P.; Cirillo, F.; Masuzzo, P.; Tringali, C.; Cabitza, P.; Tettamanti, G.; et al. Isolation and characterization of 2 new human rotator cuff and long head of biceps tendon cells possessing stem cell-like self-renewal and multipotential differentiation capacity. Am. J. Sports Med. 2013, 41, 1653-1664. [CrossRef] 
170. Ellera Gomes, J.L.; da Silva, R.C.; Silla, L.M.; Abreu, M.R.; Pellanda, R. Conventional rotator cuff repair complemented by the aid of mononuclear autologous stem cells. Knee Surg. Sports Traumatol. Arthrosc. 2012, 20, 373-377. [CrossRef]

171. Coombes, B.K.; Bisset, L.; Vicenzino, B. Efficacy and safety of corticosteroid injections and other injections for management of tendinopathy: A systematic review of randomised controlled trials. Lancet 2010, 376, 1751-1767. [CrossRef]

172. Costa-Almeida, R.; Calejo, I.; Gomes, M.E. Mesenchymal Stem Cells Empowering Tendon Regenerative Therapies. Int. J. Mol. Sci. 2019, 20, 3002. [CrossRef]

173. Luo, Q.; Song, G.; Song, Y.; Xu, B.; Qin, J.; Shi, Y. Indirect co-culture with tenocytes promotes proliferation and mRNA expression of tendon/ligament related genes in rat bone marrow mesenchymal stem cells. Cytotechnology 2009, 61, 1-10. [CrossRef]

174. Wu, T.; Liu, Y.; Wang, B.; Sun, Y.; Xu, J.; Yuk-Wai, L.W.; Xu, L.; Zhang, J.; Li, G. The Use of Cocultured Mesenchymal Stem Cells with Tendon-Derived Stem Cells as a Better Cell Source for Tendon Repair. Tissue Eng. Part A 2016, 22, 1229-1240. [CrossRef]

175. Veronesi, F.; Torricelli, P.; Della Bella, E.; Pagani, S.; Fini, M. In vitro mutual interaction between tenocytes and adipose-derived mesenchymal stromal cells. Cytotherapy 2015, 17, 215-223. [CrossRef] [PubMed]

176. Costa-Almeida, R.; Calejo, I.; Reis, R.L.; Gomes, M.E. Crosstalk between adipose stem cells and tendon cells reveals a temporal regulation of tenogenesis by matrix deposition and remodeling. J. Cell. Physiol. 2018, 233, 5383-5395. [CrossRef]

177. Costa-Almeida, R.; Berdecka, D.; Rodrigues, M.T.; Reis, R.L.; Gomes, M.E. Tendon explant cultures to study the communication between adipose stem cells and native tendon niche. J. Cell. Biochem. 2018, 119, 3653-3662. [CrossRef]

178. Petersen, W.; Tillmann, B. Structure and vascularization of the cruciate ligaments of the human knee joint. Anat. Embryol. 1999, 200, 325-334. [CrossRef] [PubMed]

179. Cimino, F.; Volk, B.S.; Setter, D. Anterior cruciate ligament injury: Diagnosis, management, and prevention. Am. Fam. Physician 2010, 82, 917-922. [PubMed]

180. Kobayashi, H.; Kanamura, T.; Koshida, S.; Miyashita, K.; Okado, T.; Shimizu, T.; Yokoe, K. Mechanisms of the anterior cruciate ligament injury in sports activities: A twenty-year clinical research of 1,700 athletes. J. Sports Sci. Med. 2010, 9, 669-675. [PubMed]

181. Fu, F.H.; van Eck, C.F.; Tashman, S.; Irrgang, J.J.; Moreland, M.S. Anatomic anterior cruciate ligament reconstruction: A changing paradigm. Knee Surg. Sports Traumatol. Arthrosc. 2015, 23, 640-648. [CrossRef]

182. Hospodar, S.J.; Miller, M.D. Controversies in ACL reconstruction: Bone-patellar tendon-bone anterior cruciate ligament reconstruction remains the gold standard. Sports Med. Arthrosc. Rev. 2009, 17, 242-246. [CrossRef] [PubMed]

183. Biau, D.J.; Tournoux, C.; Katsahian, S.; Schranz, P.; Nizard, R. ACL reconstruction: A meta-analysis of functional scores. Clin. Orthop. Relat. Res. 2007, 458, 180-187. [CrossRef]

184. Abe, S.; Kurosaka, M.; Iguchi, T.; Yoshiya, S.; Hirohata, K. Light and electron microscopic study of remodeling and maturation process in autogenous graft for anterior cruciate ligament reconstruction. Arthroscopy 1993, 9, 394-405. [CrossRef]

185. Haddad-Weber, M.; Prager, P.; Kunz, M.; Seefried, L.; Jakob, F.; Murray, M.M.; Evans, C.H.; Noth, U.; Steinert, A.F. BMP12 and BMP13 gene transfer induce ligamentogenic differentiation in mesenchymal progenitor and anterior cruciate ligament cells. Cytotherapy 2010, 12, 505-513. [CrossRef] [PubMed]

186. Canseco, J.A.; Kojima, K.; Penvose, A.R.; Ross, J.D.; Obokata, H.; Gomoll, A.H.; Vacanti, C.A. Effect on ligament marker expression by direct-contact co-culture of mesenchymal stem cells and anterior cruciate ligament cells. Tissue Eng. Part A 2012, 18, 2549-2558. [CrossRef]

187. Fan, H.; Liu, H.; Wong, E.J.; Toh, S.L.; Goh, J.C. In vivo study of anterior cruciate ligament regeneration using mesenchymal stem cells and silk scaffold. Biomaterials 2008, 29, 3324-3337. [CrossRef]

188. Ju, Y.J.; Muneta, T.; Yoshimura, H.; Koga, H.; Sekiya, I. Synovial mesenchymal stem cells accelerate early remodeling of tendon-bone healing. Cell Tissue Res. 2008, 332, 469-478. [CrossRef]

189. Sakaguchi, Y.; Sekiya, I.; Yagishita, K.; Muneta, T. Comparison of human stem cells derived from various mesenchymal tissues: Superiority of synovium as a cell source. Arthritis Rheum. 2005, 52, 2521-2529. [CrossRef]

190. Steinert, A.F.; Kunz, M.; Prager, P.; Barthel, T.; Jakob, F.; Noth, U.; Murray, M.M.; Evans, C.H.; Porter, R.M. Mesenchymal stem cell characteristics of human anterior cruciate ligament outgrowth cells. Tissue Eng. Part A 2011, 17, 1375-1388. [CrossRef]

191. Cheng, M.T.; Yang, H.W.; Chen, T.H.; Lee, O.K. Isolation and characterization of multipotent stem cells from human cruciate ligaments. Cell Prolif. 2009, 42, 448-460. [CrossRef]

192. Eagan, M.J.; Zuk, P.A.; Zhao, K.W.; Bluth, B.E.; Brinkmann, E.J.; Wu, B.M.; McAllister, D.R. The suitability of human adiposederived stem cells for the engineering of ligament tissue. J. Tissue Eng. Regen. Med. 2012, 6, 702-709. [CrossRef] [PubMed]

193. Proffen, B.L.; Haslauer, C.M.; Harris, C.E.; Murray, M.M. Mesenchymal stem cells from the retropatellar fat pad and peripheral blood stimulate ACL fibroblast migration, proliferation, and collagen gene expression. Connect. Tissue Res. 2013, 54, 14-21. [CrossRef] [PubMed]

194. Lee, I.C.; Wang, J.H.; Lee, Y.T.; Young, T.H. The differentiation of mesenchymal stem cells by mechanical stress or/and co-culture system. Biochem. Biophys. Res. Commun. 2007, 352, 147-152. [CrossRef]

195. Altman, G.H.; Horan, R.L.; Martin, I.; Farhadi, J.; Stark, P.R.; Volloch, V.; Richmond, J.C.; Vunjak-Novakovic, G.; Kaplan, D.L. Cell differentiation by mechanical stress. FASEB J. 2002, 16, 270-272. [CrossRef]

196. Fomekong, E.; Dufrane, D.; Berg, B.V.; André, W.; Aouassar, N.; Veriter, S.; Raftopoulos, C. Application of a three-dimensional graft of autologous osteodifferentiated adipose stem cells in patients undergoing minimally invasive transforaminal lumbar interbody fusion: Clinical proof of concept. Acta Neurochir. 2017, 159, 527-536. [CrossRef] 
197. Kumar, H.; Ha, D.H.; Lee, E.J.; Park, J.H.; Shim, J.H.; Ahn, T.K.; Kim, K.T.; Ropper, A.E.; Sohn, S.; Kim, C.H.; et al. Safety and tolerability of intradiscal implantation of combined autologous adipose-derived mesenchymal stem cells and hyaluronic acid in patients with chronic discogenic low back pain: 1-year follow-up of a phase I study. Stem Cell Res. Ther. 2017, 8, 262. [CrossRef]

198. Coenen, P.; Smith, A.; Paananen, M.; O'Sullivan, P.; Beales, D.; Straker, L. Trajectories of Low Back Pain From Adolescence to Young Adulthood. Arthritis Care Res. 2017, 69, 403-412. [CrossRef]

199. Wiltse, L.L.; Winter, R.B. Terminology and measurement of spondylolisthesis. J. Bone Jt. Surg. Am. 1983, 65, 768-772. [CrossRef]

200. Kalichman, L.; Kim, D.H.; Li, L.; Guermazi, A.; Berkin, V.; Hunter, D.J. Spondylolysis and spondylolisthesis: Prevalence and association with low back pain in the adult community-based population. Spine 2009, 34, 199-205. [CrossRef]

201. de Leon-Casasola, O.A. Opioids for chronic pain: New evidence, new strategies, safe prescribing. Am. J. Med. 2013,126 (Suppl. 1), S3-S11. [CrossRef]

202. Fritz, J.M.; Lurie, J.D.; Zhao, W.; Whitman, J.M.; Delitto, A.; Brennan, G.P.; Weinstein, J.N. Associations between physical therapy and long-term outcomes for individuals with lumbar spinal stenosis in the SPORT study. Spine J. 2014, 14, 1611-1621. [CrossRef] [PubMed]

203. Manchikanti, L.; Cash, K.A.; McManus, C.D.; Pampati, V.; Fellows, B. Results of 2-year follow-up of a randomized, double-blind, controlled trial of fluoroscopic caudal epidural injections in central spinal stenosis. Pain Physician 2012, 15, 371-384. [CrossRef]

204. Weinstein, J.N.; Tosteson, T.D.; Lurie, J.D.; Tosteson, A.N.; Blood, E.; Hanscom, B.; Herkowitz, H.; Cammisa, F.; Albert, T.; Boden, S.D.; et al. Surgical versus nonsurgical therapy for lumbar spinal stenosis. N. Engl. J. Med. 2008, 358, 794-810. [CrossRef] [PubMed]

205. Tarpada, S.P.; Morris, M.T.; Burton, D.A. Spinal fusion surgery: A historical perspective. J. Orthop. 2017, 14, 134-136. [CrossRef] [PubMed]

206. Kim, D.H.; Rhim, R.; Li, L.; Martha, J.; Swaim, B.H.; Banco, R.J.; Jenis, L.G.; Tromanhauser, S.G. Prospective study of iliac crest bone graft harvest site pain and morbidity. Spine J. 2009, 9, 886-892. [CrossRef] [PubMed]

207. Heneghan, H.M.; McCabe, J.P. Use of autologous bone graft in anterior cervical decompression: Morbidity \& quality of life analysis. BMC Musculoskelet. Disord. 2009, 10, 158.

208. Morris, M.T.; Tarpada, S.P.; Cho, W. Bone graft materials for posterolateral fusion made simple: A systematic review. Eur. Spine J. 2018, 27, 1856-1867. [CrossRef]

209. Salamanna, F.; Sartori, M.; Brodano, G.B.; Griffoni, C.; Martini, L.; Boriani, S.; Fini, M. Mesenchymal Stem Cells for the Treatment of Spinal Arthrodesis: From Preclinical Research to Clinical Scenario. Stem Cells Int. 2017, 2017, 3537094. [CrossRef]

210. Sheyn, D.; Ruthemann, M.; Mizrahi, O.; Kallai, I.; Zilberman, Y.; Tawackoli, W.; Kanim, L.E.; Zhao, L.; Bae, H.; Pelled, G.; et al Genetically modified mesenchymal stem cells induce mechanically stable posterior spine fusion. Tissue Eng. Part A 2010, 16, 3679-3686. [CrossRef]

211. Garcia de Frutos, A.; Gonzalez-Tartiere, P.; Coll Bonet, R.; Ubierna Garces, M.T.; Del Arco Churruca, A.; Rivas Garcia, A.; Matamalas Adrover, A.; Salo Bru, G.; Velazquez, J.J.; Vila-Canet, G.; et al. Randomized clinical trial: Expanded autologous bone marrow mesenchymal cells combined with allogeneic bone tissue, compared with autologous iliac crest graft in lumbar fusion surgery. Spine J. 2020, 20, 1899-1910. [CrossRef] [PubMed]

212. Hoy, D.; March, L.; Brooks, P.; Blyth, F.; Woolf, A.; Bain, C.; Williams, G.; Smith, E.; Vos, T.; Barendregt, J.; et al. The global burden of low back pain: Estimates from the Global Burden of Disease 2010 study. Ann. Rheum. Dis. 2014, 73, 968-974. [CrossRef] [PubMed]

213. Raastad, J.; Reiman, M.; Coeytaux, R.; Ledbetter, L.; Goode, A.P. The association between lumbar spine radiographic features and low back pain: A systematic review and meta-analysis. Semin. Arthritis Rheum. 2015, 44, 571-585. [CrossRef] [PubMed]

214. Navani, A.; Manchikanti, L.; Albers, S.L.; Latchaw, R.E.; Sanapati, J.; Kaye, A.D.; Atluri, S.; Jordan, S.; Gupta, A.; Cedeno, D.; et al Responsible, Safe, and Effective Use of Biologics in the Management of Low Back Pain: American Society of Interventional Pain Physicians (ASIPP) Guidelines. Pain Physician 2019, 22, S1-S74. [PubMed]

215. Manchikanti, L.; Kaye, A.M.; Knezevic, N.N.; McAnally, H.; Slavin, K.; Trescot, A.M.; Blank, S.; Pampati, V.; Abdi, S.; Grider, J.S.; et al. Responsible, Safe, and Effective Prescription of Opioids for Chronic Non-Cancer Pain: American Society of Interventional Pain Physicians (ASIPP) Guidelines. Pain Physician 2017, 20, S3-S92. [CrossRef] [PubMed]

216. van Middelkoop, M.; Rubinstein, S.M.; Kuijpers, T.; Verhagen, A.P.; Ostelo, R.; Koes, B.W.; van Tulder, M.W. A systematic review on the effectiveness of physical and rehabilitation interventions for chronic non-specific low back pain. Eur. Spine J. 2011, 20, 19-39. [CrossRef] [PubMed]

217. Manchikanti, L.; Staats, P.S.; Nampiaparampil, D.E.; Hirsch, J.A. What is the Role of Epidural Injections in the Treatment of Lumbar Discogenic Pain: A Systematic Review of Comparative Analysis with Fusion. Korean J. Pain 2015, 28, 75-87. [CrossRef]

218. Zhao, L.; Manchikanti, L.; Kaye, A.D.; Abd-Elsayed, A. Treatment of Discogenic Low Back Pain: Current Treatment Strategies and Future Options-a Literature Review. Curr. Pain Headache Rep. 2019, 23, 86. [CrossRef] [PubMed]

219. Fleege, C.; Rickert, M.; Rauschmann, M. The PLIF and TLIF techniques. Indication, technique, advantages, and disadvantages. Orthopade 2015, 44, 114-123. [CrossRef] [PubMed]

220. Garcia, R., Jr.; Yue, J.J.; Blumenthal, S.; Coric, D.; Patel, V.V.; Leary, S.P.; Dinh, D.H.; Buttermann, G.R.; Deutsch, H.; Girardi, F.; et al. Lumbar Total Disc Replacement for Discogenic Low Back Pain: Two-year Outcomes of the activL Multicenter Randomized Controlled IDE Clinical Trial. Spine 2015, 40, 1873-1881. [CrossRef] [PubMed] 
221. Zagra, A.; Minoia, L.; Archetti, M.; Corriero, A.S.; Ricci, K.; Teli, M.; Giudici, F. Prospective study of a new dynamic stabilisation system in the treatment of degenerative discopathy and instability of the lumbar spine. Eur. Spine J. 2012, 21 (Suppl. 1), S83-S89. [CrossRef]

222. Monfett, M.; Harrison, J.; Boachie-Adjei, K.; Lutz, G. Intradiscal platelet-rich plasma (PRP) injections for discogenic low back pain: An update. Int. Orthop. 2016, 40, 1321-1328. [CrossRef] [PubMed]

223. Levi, D.; Horn, S.; Tyszko, S.; Levin, J.; Hecht-Leavitt, C.; Walko, E. Intradiscal Platelet-Rich Plasma Injection for Chronic Discogenic Low Back Pain: Preliminary Results from a Prospective Trial. Pain Med. 2016, 17, 1010-1022. [CrossRef] [PubMed]

224. Tschugg, A.; Diepers, M.; Simone, S.; Michnacs, F.; Quirbach, S.; Strowitzki, M.; Meisel, H.J.; Thome, C. A prospective randomized multicenter phase I/II clinical trial to evaluate safety and efficacy of NOVOCART disk plus autologous disk chondrocyte transplantation in the treatment of nucleotomized and degenerative lumbar disks to avoid secondary disease: Safety results of Phase I-a short report. Neurosurg. Rev. 2017, 40, 155-162. [PubMed]

225. Orozco, L.; Soler, R.; Morera, C.; Alberca, M.; Sanchez, A.; Garcia-Sancho, J. Intervertebral disc repair by autologous mesenchymal bone marrow cells: A pilot study. Transplantation 2011, 92, 822-828. [CrossRef] [PubMed]

226. Noriega, D.C.; Ardura, F.; Hernandez-Ramajo, R.; Martin-Ferrero, M.A.; Sanchez-Lite, I.; Toribio, B.; Alberca, M.; Garcia, V.; Moraleda, J.M.; Sanchez, A.; et al. Intervertebral Disc Repair by Allogeneic Mesenchymal Bone Marrow Cells: A Randomized Controlled Trial. Transplantation 2017, 101, 1945-1951. [CrossRef]

227. Zhao, C.Q.; Wang, L.M.; Jiang, L.S.; Dai, L.Y. The cell biology of intervertebral disc aging and degeneration. Ageing Res. Rev. 2007, 6, 247-261. [CrossRef]

228. Haefeli, M.; Kalberer, F.; Saegesser, D.; Nerlich, A.G.; Boos, N.; Paesold, G. The course of macroscopic degeneration in the human lumbar intervertebral disc. Spine 2006, 31, 1522-1531. [CrossRef]

229. Clouet, J.; Fusellier, M.; Camus, A.; Le Visage, C.; Guicheux, J. Intervertebral disc regeneration: From cell therapy to the development of novel bioinspired endogenous repair strategies. Adv. Drug Deliv. Rev. 2019, 146, 306-324. [CrossRef]

230. Le Maitre, C.L.; Baird, P.; Freemont, A.J.; Hoyland, J.A. An in vitro study investigating the survival and phenotype of mesenchymal stem cells following injection into nucleus pulposus tissue. Arthritis Res. Ther. 2009, 11, R20. [CrossRef]

231. Sakai, D.; Mochida, J.; Iwashina, T.; Watanabe, T.; Nakai, T.; Ando, K.; Hotta, T. Differentiation of mesenchymal stem cells transplanted to a rabbit degenerative disc model: Potential and limitations for stem cell therapy in disc regeneration. Spine 2005, 30, 2379-2387. [CrossRef]

232. Richardson, S.M.; Walker, R.V.; Parker, S.; Rhodes, N.P.; Hunt, J.A.; Freemont, A.J.; Hoyland, J.A. Intervertebral disc cell-mediated mesenchymal stem cell differentiation. Stem Cells 2006, 24, 707-716. [CrossRef] [PubMed]

233. Henriksson, H.B.; Papadimitriou, N.; Hingert, D.; Baranto, A.; Lindahl, A.; Brisby, H. The Traceability of Mesenchymal Stromal Cells After Injection Into Degenerated Discs in Patients with Low Back Pain. Stem Cells Dev. 2019, 28, 1203-1211. [CrossRef]

234. Vadala, G.; Studer, R.K.; Sowa, G.; Spiezia, F.; Iucu, C.; Denaro, V.; Gilbertson, L.G.; Kang, J.D. Coculture of bone marrow mesenchymal stem cells and nucleus pulposus cells modulate gene expression profile without cell fusion. Spine 2008, 33, 870-876. [CrossRef] [PubMed]

235. Yang, S.H.; Wu, C.C.; Shih, T.T.; Sun, Y.H.; Lin, F.H. In vitro study on interaction between human nucleus pulposus cells and mesenchymal stem cells through paracrine stimulation. Spine 2008, 33, 1951-1957. [CrossRef]

236. Lu, K.; Li, H.Y.; Yang, K.; Wu, J.L.; Cai, X.W.; Zhou, Y.; Li, C.Q. Exosomes as potential alternatives to stem cell therapy for intervertebral disc degeneration: In-vitro study on exosomes in interaction of nucleus pulposus cells and bone marrow mesenchymal stem cells. Stem Cell Res. Ther. 2017, 8, 108. [CrossRef] [PubMed]

237. Risbud, M.V.; Shapiro, I.M. Role of cytokines in intervertebral disc degeneration: Pain and disc content. Nat. Rev. Rheumatol. 2014, 10, 44-56. [CrossRef]

238. Le Maitre, C.L.; Freemont, A.J.; Hoyland, J.A. The role of interleukin-1 in the pathogenesis of human intervertebral disc degeneration. Arthritis Res. Ther. 2005, 7, R732-R745. [CrossRef] [PubMed]

239. Johnson, Z.I.; Schoepflin, Z.R.; Choi, H.; Shapiro, I.M.; Risbud, M.V. Disc in flames: Roles of TNF-alpha and IL-1beta in intervertebral disc degeneration. Eur. Cells Mater. 2015, 30, 104-116; discussion 116-117. [CrossRef]

240. Lyu, F.J.; Cheung, K.M.; Zheng, Z.; Wang, H.; Sakai, D.; Leung, V.Y. IVD progenitor cells: A new horizon for understanding disc homeostasis and repair. Nat. Rev. Rheumatol. 2019, 15, 102-112. [CrossRef]

241. Miguelez-Rivera, L.; Perez-Castrillo, S.; Gonzalez-Fernandez, M.L.; Prieto-Fernandez, J.G.; Lopez-Gonzalez, M.E.; GarciaCosamalon, J.; Villar-Suarez, V. Immunomodulation of mesenchymal stem cells in discogenic pain. Spine J. 2018, 18, 330-342. [CrossRef] [PubMed]

242. Teixeira, G.Q.; Pereira, C.L.; Ferreira, J.R.; Maia, A.F.; Gomez-Lazaro, M.; Barbosa, M.A.; Neidlinger-Wilke, C.; Goncalves, R.M. Immunomodulation of Human Mesenchymal Stem/Stromal Cells in Intervertebral Disc Degeneration: Insights from a Proinflammatory/Degenerative Ex Vivo Model. Spine 2018, 43, E673-E682. [CrossRef] [PubMed]

243. Sebbag, E.; Felten, R.; Sagez, F.; Sibilia, J.; Devilliers, H.; Arnaud, L. The world-wide burden of musculoskeletal diseases: A systematic analysis of the World Health Organization Burden of Diseases Database. Ann. Rheum. Dis. 2019, 78, 844-848. [CrossRef] [PubMed] 